\title{
Differential effects of $16 a$-hydroxyestrone and 2-methoxyestradiol on cyclin D1 involving the transcription factor ATF-2 in MCF-7 breast cancer cells
}

\author{
Joan S Lewis ${ }^{1}$, T J Thomas ${ }^{1,5}$, Richard G Pestell ${ }^{4}$, Chris Albanese ${ }^{4}$, Michael A Gallo,3,5 \\ and Thresia Thomas ${ }^{2,3,5}$ \\ ${ }^{1}$ Department of Medicine and ${ }^{2}$ Department of Environmental and Occupational Medicine, University of Medicine and Dentistry of New Jersey - Robert Wood Johnson Medical \\ School, New Brunswick, NJ 08903, USA \\ ${ }^{3}$ Environmental and Occupational Health Sciences Institute and ${ }^{4}$ Department of Oncology, Lombardi Cancer Center, Georgetown University, Washington DC 20057, USA \\ ${ }^{5}$ The Cancer Institute of New Jersey, New Brunswick, New Jersey 08903, USA
}

(Requests for offprints should be addressed to T Thomas, Clinical Academic Building, Room 7092, UMDNJ - Robert Wood Johnson Medical School, 125 Paterson Street, New Brunswick, New Jersey 08903, USA; Email: thomasth@UMDNJ.edu)

\begin{abstract}
We studied the effects of 2-methoxyestradiol $\left(2-\mathrm{ME}_{2}\right)$ and $16 \alpha$-hydroxyestrone $\left(16 \alpha-\mathrm{OHE}_{1}\right)$, two metabolites of estradiol $\left(E_{2}\right)$, on DNA synthesis, cell cycle progression and cyclin D1 protein levels in estrogen receptor-positive MCF-7 cells. $\mathrm{E}_{2}$ and $16 \alpha-\mathrm{OHE}_{1}$ stimulated DNA synthesis, and 2-ME $\mathrm{M}_{2}$ inhibited the stimulatory effects of these agents. $E_{2}$ and $16 \alpha-\mathrm{OHE}_{1}$ stimulated the progression of cells from $\mathrm{G}_{1}$ to $S$ phase and this effect was attenuated by $2-\mathrm{ME}_{2}$. Western blot analysis showed that $\mathrm{E}_{2}$ and $16 \alpha-\mathrm{OHE}_{1}$ increased cyclin $\mathrm{D} 1$ protein level by about fourfold compared with control. 2-ME $\mathrm{ME}_{2}$ had no significant effect on cyclin D1; however, it prevented the accumulation of cyclin D1 in the presence of $\mathrm{E}_{2}$ and $16 \alpha-\mathrm{OHE}_{1}$. Cells transfected with a cyclin $\mathrm{D} 1$ reporter gene and treated with $\mathrm{E}_{2}$ or $16 \alpha-\mathrm{OHE}_{1}$ showed 7- and 9.5-fold increase respectively in promoter activity compared with control. This activity was significantly inhibited by $2-\mathrm{ME}_{2}$. Cyclin D1 transactivation was mediated by the cAMP response element (CRE) region, which binds activating transcription factor 2 (ATF-2). DNA affinity assay showed 2.5- and 3.5-fold increases in ATF-2 binding to CRE in the presence of $E_{2}$ and $16 \alpha-O H E_{1}$ respectively. The binding of ATF-2 was inhibited by the presence of 2-ME These results show that $2-\mathrm{ME}_{2}$ can downregulate cyclin $\mathrm{D} 1$ and thereby cell cycle progression by a mechanism involving the disruption of ATF-2 binding to cyclin D1 promoter.
\end{abstract}

Journal of Molecular Endocrinology (2005) 34, 91-105

\section{Introduction}

The female sex hormone estradiol $\left(\mathrm{E}_{2}\right)$ plays a major role in the development and progression of breast cancer (Henderson et al. 1988, Russo et al. 2003). $\mathrm{E}_{2}$ exerts its biologic effects through the estrogen receptors (ER $\alpha$ and ER $\beta$ ), ligand-activated transcription factors present in target tissues (Katzenellenbogen et al. 2000, McKenna \& O'Malley 2002, Thomas et al. 2004). In general, estrogenic action involves the binding of the ligand to the ER, which undergoes conformational changes and dimerization, and is recognized by the estrogen response element (ERE), located at the promoter region of estrogen-responsive genes. The ER-ERE interaction triggers a cascade of cellular events, leading to the transcriptional activation of specific genes responsible for cell proliferation (Nilsson \& Gustafsson 2002).

$\mathrm{E}_{2}$ is metabolized by oxidation and hydroxylation (Martucci \& Fishman 1993, Zhu \& Conney 1998). The oxidation product of $\mathrm{E}_{2}$ is estrone $\left(\mathrm{E}_{1}\right)$, which is metabolized by two mutually exclusive hydroxylation pathways: hydroxylation at the C-2 or the $16 \alpha$ position (Fig. 1). Hydroxylation at the C-2 position yields 2-hydroxyestrone $\left(2-\mathrm{OHE}_{1}\right)$ and 2-hydroxyestradiol $\left(2-\mathrm{OHE}_{2}\right)$, whereas hydroxylation at the $16 \alpha$ position yields $16 \alpha$-hydroxyestrone $\left(16 \alpha-\mathrm{OHE}_{1}\right)$ and $16 \alpha$ hydroxyestradiol $\left(16 \alpha-\mathrm{OHE}_{2}\right)$. Increased 16 $\alpha$-hydroxylation in women is associated with increased breast cancer risk (Muti et al. 2000). 16 $\alpha$-Hydroxylated metabolites stimulate breast cancer cell growth, whereas the 2-hydroxylated estrogens inhibit cell growth (Ball et al. 1972, Seegers et al. 1989, Lottering et al. 1992, Zhu \& Conney 1998). 2- $\mathrm{OHE}_{1}$ and $2-\mathrm{OHE}_{2}$ are rapidly converted to the monomethyl ethers, $2-\mathrm{ME}_{1}$ and $2-\mathrm{ME}_{2}$ respectively by the enzyme catechol- $O$-methyltransferase (COMT) (Ball et al. 1972, Jefcoate et al. 2000). 2-ME 2 inhibits the growth of human mammary cancer cells in vitro and in vivo (Lottering et al. 1992, Fotis et al. 1994). The binding affinity $2-\mathrm{ME}_{2}$ for ER from MCF-7 cells is about $1 \%$ of that of $\mathrm{E}_{2}$ (Brueggemeier et al. 2001). Low concentrations $(10 \mathrm{nM})$ of $2-\mathrm{ME}_{2}$ inhibit the growth of ER-positive MCF-7 cells, and cause 
<smiles>COc1cc2c(cc1O)CCC1c3cc(O)c(O)cc3CCC21CCC(C)C</smiles>

2-Hydroxyestrone 2-Hydroxyestradiol 2-Methoxyestradiol C2-Hydroxylation

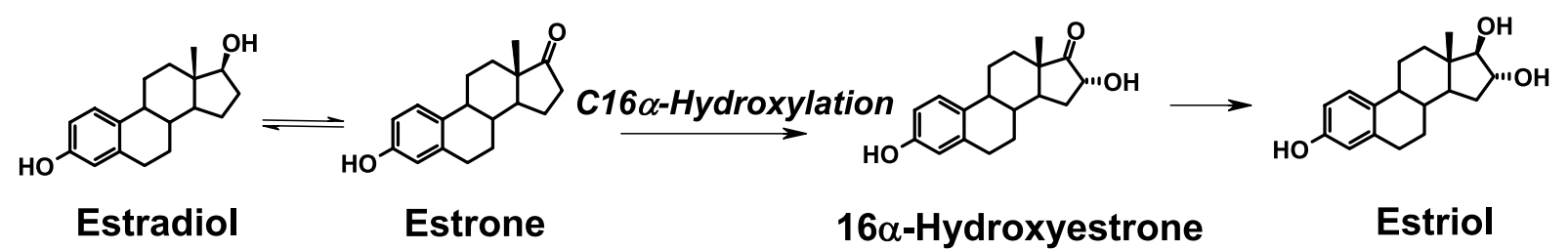
C4-Hydroxylation<smiles>C=C1CCC2C1CCC1C3CCC(C)(CCC21)c1c3ccc(O)c1O</smiles>

4-Hydroxyestrone<smiles>CC1(O)CCC2C3CCc4c(ccc(O)c4O)C3CCC21</smiles>

4-Hydroxyestradiol

Figure 1 Pathways of cellular metabolism of estradiol $\left(E_{2}\right)$. $E_{2}$ metabolism occurs primarily through three pathways: C2-hydroxylation (major pathway), C16a-hydroxylation (major pathway) and C4-hydroxylation (minor pathway). 2-Hydroxyestradiol $\left(2-\mathrm{OHE}_{2}\right)$ is further $\mathrm{O}$-methylated by catechol-O-methyltransferase (COMT) to form 2-methoxyestradiol 2-ME . .

fluctuations in cAMP levels, whereas pharmacologic concentrations $(1-10 \mu \mathrm{M})$ inhibit tubulin polymerization and angiogenesis (Lottering et al. 1992, D'Amato et al. 1994, Cushman et al. 1995, Klauber et al. 1997, Moobery 2003).

In contrast to the growth-inhibitory effects of 2-ME on MCF-7 cells, $16 \alpha-\mathrm{OHE}_{1}$ stimulates the proliferation of these cells (Gupta et al. 1998, Suto et al. 1999). $16 \alpha-\mathrm{OHE}_{1}$ binds to the ER with measurable affinity and exerts uterotropic activity, comparable to that of $\mathrm{E}_{2}$ (Fishman \& Martucci 1980). We found that $16 \alpha-\mathrm{OHE}_{1}$ and $\mathrm{E}_{2}$ had comparable effects on cell cycle kinetics and in stimulating the expression of cyclin D1 in MCF-7 cells (Lewis et al. 2001).

Cyclin D1 is an important regulator of $\mathrm{G}_{1} \rightarrow \mathrm{S}$ phase transition, and its expression in breast cancer cells is sensitive to estrogens and antiestrogens (Musgrove et al. 1994, Altucci et al. 1996, Foster \& Wimalasena 1996, Pacilio et al. 1998, Pestell et al. 1999). In transgenic mice, overexpression of cyclin D1 led to the development of mammary tumors, while cyclin D1 knockout mice showed impaired development of mammary glands (Wang et al. 1994, Sicinski \& Weinberg 1997). The promoter region of cyclin D1 contains binding sites for

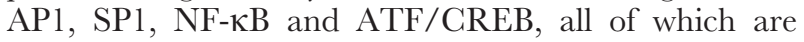
implicated in its transcriptional activation (Herber et al. 1994, Albanese et al. 1995, Watanabe et al. 1998, Bromberg et al. 1999, Guttridge et al. 1999). Recent studies indicate that $\mathrm{E}_{2}$ regulation of cyclin $\mathrm{D} 1$ in MCF-7 cells occurs at the transcriptional level, and involves the cAMP response element (CRE) (Altucci et al. 1996, Sabbah et al. 1999). The CRE element binds bZIP DNA-binding proteins belonging to the ATF/CREB family of transcription factors (Hai et al. 1993). ATF-2 is a member of the ATF/CREB family, and stimulates the transcription of cyclin D1 (Beier et al. 1999, Sabbah et al. 1999). The ability of ATF-2 to bind to the CRE and stimulate CRE-mediated transcription is regulated by phosphorylation (Gupta et al. 1995).

In the present study, we examined the effects of $\mathrm{E}_{2}$, $16 \alpha-\mathrm{OHE}_{1}$ and $2-\mathrm{ME}_{2}$ on DNA synthesis and cell cycle progression, cyclin D1 transactivation and ATF-2 DNA-binding activity in MCF-7 breast cancer cells. Our results showed that $2-\mathrm{ME}_{2}$ interfered with the growth stimulatory effects of $\mathrm{E}_{2}$ and $16 \alpha-\mathrm{OHE}_{1}$, as did the pure antiestrogen, ICI 182,780. In transient transfection 
assays, $\mathrm{E}_{2}$ and $16 \alpha-\mathrm{OHE}_{1}$ enhanced cyclin $\mathrm{D} 1$ promoter activity, while $2-\mathrm{ME}_{2}$ and ICI 182,780 inhibited this effect. The estrogenic effect on cyclin D1 was mediated through the binding of ATF-2 to the GRE site.

\section{Materials and methods}

\section{Chemicals, reagents and antibodies}

$\mathrm{E}_{2}, \quad 16 \alpha-\mathrm{OHE}_{1}$ and $2-\mathrm{ME}_{2}$ were purchased from Steraloids (Wilton, NH, USA). The pure antiestrogen ICI 182,780 was purchased from Tocris (Ellisville, MO, USA). Monoclonal antihuman ATF-2, phospho-ATF-2, CREB, ATF-1, c-Jun, c-Fos, p65, p50, p38 and phospho-p38 antibodies were purchased from Santa Cruz Biotechnology (Santa Cruz, CA, USA). Monoclonal anti-cyclin Dl antibody was from LabVision (Fremont, CA, USA). DMEM, phenol red-free DMEM and fetal bovine serum were purchased from Sigma. The HexaPlus DNA labeling kit was obtained from MBI Fermentas (Amherst, NY, USA). Antibiotics, trypsin and other additives for cell culture were purchased from Gibco Laboratories (Grand Island, NY, USA). Dynabeads M-280, Streptavidin and Dynal MPC-S were obtained from Dynal Biotechnology (Lake Success, NY, USA). Biotin-16-2'-deoxyuridine-5'triphosphate (Biotin-16-dUTP) was purchased from Sigma.

\section{Oligonucleotides and plasmids}

HPLC-purified oligonucleotides (ODNs) were purchased from Oligos, Etc (Wilsonville, OR, USA). A 74-bp ODN1, with cyclin D1 promoter sequence $(-78$ to -5$)$ containing the consensus CRE (underlined) and NF- $\mathrm{KB}$ response element (boldface) was used for DNA affinity assays. A mutated CRE/ATF ODN2 with a three-base rearrangement in the consensus sequence (underlined and boldface) was used for determining sequence specificity of the CRE/ATF-2 binding. The base sequence of the top strands of the ODNs used in this study are as follows:

ODN1: 5'-GGGCTTTGATGTTTGCTTAAGAAG AGTAACGTCACACGGACTACAGGGGAGTTTTG TTGAAGTTGCAAAGTCGT-3'

ODN2: 5'GGGGTTTGATGTTTGCTTAACAAC AGTAGCGGCACACGGACTACAGGGGAGTTTT GTTGAAGTTGCAAAGTCCT-3'

For transcriptional activation studies, the cyclin D1 luciferase reporter plasmids -1745CD1-LUC, -1745 ATF/CREmut-LUC, -964CD1-LUC, -964AP1 mutLUC, -66CD1-LUC, -66 ATF/CREmut-LUG and $-66 \mathrm{CD} 1 \kappa$ Bmut-LUC were used. These reporter gene constructs have been previously described (Albanese et al. 1995, Watanabe et al. 1999). A mutant and wild-type human ATF-2 cDNA, subcloned into the eukaryotic expression vector pCMV, was used to express
ATF-2 dominant negative mutant (ATF-2 dom neg mutant) and wild-type proteins in transfected cells (Lee et al. 1999, D'Amico et al. 2000). The pRL-SV40 vector (Promega) containing the Renilla luciferase gene was used as an internal control.

\section{Cell culture methods}

MCF-7 cells were obtained from the American Type Culture Collection (Rockville, MD, USA). Cells were maintained in DMEM, supplemented with 100 units $/ \mathrm{ml}$ penicillin, $100 \mu \mathrm{g} / \mathrm{ml}$ streptomycin, $40 \mu \mathrm{g} / \mathrm{ml}$ gentamicin, $2 \mu \mathrm{g} / \mathrm{ml}$ insulin, $0.5 \mathrm{mM}$ sodium pyruvate, $50 \mathrm{mM}$ nonessential amino acids, $2 \mathrm{mM}$ L-glutamine and $10 \%$ fetal bovine serum. Two weeks before each experiment, MCF-7 cells were grown in phenol red-free DMEM containing serum treated with dextran-coated charcoal (DCG) to remove serum-derived estrogenic compounds (Berthois et al. 1986, Thomas et al. 1989, Lewis et al. 2001). DCG suspension contained $0 \cdot 05 \%$ dextran, $0 \cdot 5 \%$ charcoal and $25 \mathrm{mM}$ sucrose. Serum was subjected to three 10-min cycles of DCG treatment, centrifugation and filtering through a $0 \cdot 2 \mu \mathrm{m}$ membrane.

For $\left[{ }^{3} \mathrm{H}\right]$ thymidine incorporation assay, MCF-7 cells $\left(0.5 \times 10^{6}\right)$ were seeded in $35 \mathrm{~mm}$ culture dishes in phenol red-free DMEM supplemented with DCGtreated serum and additives. After $24 \mathrm{~h}$ of plating, cells were treated with $10 \mathrm{nM} \mathrm{E}{ }_{2}, 16 \alpha-\mathrm{OHE}_{1}$ or $2-\mathrm{ME}_{2}$, as indicated in the text. Control cells received ethanol vehicle, which was maintained at less than $0 \cdot 1 \%$. DNA synthesis was measured by adding $4 \mu \mathrm{Ci} / \mathrm{ml}\left[{ }^{3} \mathrm{H}\right]$ thymidine to cells $1 \mathrm{~h}$ before harvest. Cells were washed twice with ice-cold PBS and treated with ice-cold 5\% trichloroacetic acid. The cell layer was then solubilized in $1 \mathrm{M} \mathrm{NaOH}$ and neutralized with $1 \mathrm{M} \mathrm{HCl}$. The radioactive thymidine incorporated in cellular DNA was quantified by liquid scintillation counting.

For cell cycle analysis, MCF-7 cells $\left(2 \times 10^{6}\right)$ were seeded in $100 \mathrm{~mm}$ culture dishes for $24 \mathrm{~h}$ and then treated with $\mathrm{E}_{2}, 16 \alpha-\mathrm{OHE}_{1}, 2-\mathrm{ME}_{2}$ or ICI 182,780 for 24 and $48 \mathrm{~h}$. Triplicate plates from each treatment group were washed with PBS and covered with a buffer containing $40 \mathrm{mM}$ sodium citrate, $250 \mathrm{mM}$ sucrose and $5 \%$ DMSO, and stored at $-70{ }^{\circ} \mathrm{C}$. On the day of DNA analysis, cells were thawed, and the citrate buffer was removed. Cells were trypsinized for $10 \mathrm{~min}$ and then treated with a solution containing a trypsin inhibitor and RNase for $10 \mathrm{~min}$. Cells were then stained by adding propidium iodide solution in sodium citrate buffer and analyzed by a Coulter flow cytometer. Percentage distribution of cells in different phases of cell cycle was calculated with cytologic software (Thomas \& Thomas 1994).

\section{Western blot analysis}

Gyclin D1 protein levels in MCF-7 cells were determined by Western blot, after treatment with $\mathrm{E}_{2}$, 
$16 \alpha-\mathrm{OHE}_{1}, 2-\mathrm{ME}_{2}$ or ICI 182,780 . Cell lysate was prepared by the procedure previously described (Thomas \& Thomas 1994). Briefly, monolayers of cells were washed twice with ice-cold PBS, and lysed by the addition of ice-cold lysis buffer $(150 \mathrm{mM}$ Tris-HCl $(\mathrm{pH}$ $7 \cdot 4), 150 \mathrm{mM} \mathrm{NaCl}, 1 \% \mathrm{NP}-40,2 \mathrm{mM}$ EDTA, $50 \mathrm{mM}$ sodium fluoride, $0 \cdot 2 \% \mathrm{SDS}, 1 \mathrm{mM}$ sodium vanadate, $2 \mu \mathrm{g} / \mathrm{ml}$ leupeptin, aprotonin and pepstatin, and $1 \mathrm{mM}$ phenylmethylsulfonyl fluoride). An amount of $30 \mu \mathrm{g}$ protein was diluted in $2 \times$ SDS-PAGE Laemmli buffer (150 mM Tris base (pH 6.8), 30\% glycerol, 4\% SDS, $7.5 \mathrm{mM}$ dithiothreitol and $0.01 \%$ bromophenol blue) and separated on 10\% SDS-polyacrylamide gel. Proteins were transferred to PVDF Polyscreen membranes, which were incubated in 5\% nonfat milk in Trisbuffered saline, containing $0 \cdot 1 \%$ Tween-20 for $1 \mathrm{~h}$. Membranes were then incubated overnight with a 1:200 dilution of antibodies specific to human cyclin D1, phospho-p38 MAPK (activated) or p38 MAPK (total) respectively. Protein bands were visualized with horseradish peroxidase-conjugated secondary antibody with a chemiluminescence-based detection system. Membranes were stripped and reblotted with anti- $\beta$-actin monoclonal antibody (1:5000). Intensity of protein bands was quantified with a Scanjet 4C flatbed scanner (Hewlett Packard) with NIH Image v1.52 software. Lightly exposed films were used for quantification.

\section{Transient transfection assay}

MCF-7 cells $\left(1 \times 10^{5}\right)$ were plated in 24-well microtiter plates for $24 \mathrm{~h}$. By the calcium phosphate coprecipitation procedure (Mamalian Transfection Kit; Clontech, Palo Alto, CA, USA), cells were transfected with $4 \mu \mathrm{g}$ cyclin D1 promoter plasmid linked to a firefly luciferase reporter gene and $0 \cdot 4 \mu \mathrm{g}$ Renilla luciferase plasmid (Shah et al. 2001). In some experiments, cells were also transfected with 1-10 $\mu \mathrm{g}$ ATF-2 dominant negative mutant expression vector (pCMV). After transfection, the medium was refreshed, and cells were treated with $10 \mathrm{nM} \mathrm{E} \mathrm{E}_{2}, 16 \alpha-\mathrm{OHE}_{1}$ or $2-\mathrm{ME}_{2}$, or $100 \mathrm{nM}$ ICI 182,780 for $7 \mathrm{~h}$. The activities of the cyclin D1 firefly reporter gene and the Renilla luciferase internal control were determined in a dual luciferase reporter assay system (Promega). Reporter activity was normalized for each sample by the following formula: normalized luciferase activity =firefly luciferase activity/Renilla luciferase activity.

\section{DNA affinity immunoblot assay}

Treatments and preparation of cellular extracts were as described under Western blot analysis.

ODNs were biotinylated with the HexaLabel Plus DNA labeling kit. Biotinylated ODNs $(1 \mu \mathrm{M})$ were immobilized by incubating with the Dynabeads
$(1 \mathrm{mg} / \mathrm{ml})$ in TE buffer $(10 \mathrm{mM}$ Tris-HCl, $\mathrm{pH} 7 \cdot 5$, $1 \mathrm{mM}$ EDTA, $1 \mathrm{M} \mathrm{NaCl}$ ) for $15 \mathrm{~min}$ at $22^{\circ} \mathrm{C}$. The Dynabeads containing the immobilized biotinylated DNA were washed, separated in Dynal MPG-S and incubated with cellular extract $(100 \mu \mathrm{g})$ in $8 \mathrm{mM}$ Tris-phosphate at $\mathrm{pH} 7 \cdot 4,0 \cdot 12 \mathrm{M} \mathrm{KCl}, 8 \%$ glycerol, $4 \mathrm{mM}$ DTT and $0.5 \%$ CHAPS for $1 \mathrm{~h}$ at $4{ }^{\circ} \mathrm{C}$ (Zwijsen et al. 1998). Subsequently, beads were washed in $10 \mathrm{mM}$ HEPES at pH 7·7, $50 \mathrm{mM} \mathrm{KCl,} 20 \%$ glycerol and $0 \cdot 1 \%$ NP-40, and boiled in Laemmli buffer $(100 \mu \mathrm{l})$, and the DNA-bound proteins were separated on $10 \%$ polyacrylamide gel. Proteins were identified by immunoblotting with antibodies specific for ATF-2, phospho-ATF-2, ATF-1, c-Fos, c-Jun, CREB or p65. Membranes were stripped and reprobed, using an antibody to a transcription factor (p50), which did not show any change with treatments, as a control for equal loading and transfer.

\section{Statistical analysis}

Results of transient transfection studies are presented as mean \pm S.E. for at least three separate experiments. Statistical difference between control and treatment groups was determined by one-way ANOVA followed by Dunnet's post-test (GraphPad Prism Software program, San Diego, CA, USA). A $P$ value of $<0 \cdot 05$ was considered to be statistically significant.

\section{Results}

\section{Effects of $\mathrm{E}_{2}, 16 \alpha-\mathrm{OHE}_{1}$ and 2-ME $\mathrm{M}_{2}$ on DNA synthesis and cell cycle}

In the first set of experiments, we tested the effects of $10 \mathrm{nM} \mathrm{E}_{2}, 16 \alpha-\mathrm{OHE}_{1}$ and $2-\mathrm{ME}_{2}$ on DNA synthesis in MCF-7 breast cancer cells by the $\left[{ }^{3} \mathrm{H}\right]$ thymidine incorporation assay. A concentration of $10 \mathrm{nM}$ was used to observe maximal effects of $\mathrm{E}_{2}$ and $16 \alpha-\mathrm{OHE}_{1}$ (Lewis et al. 2001) and to avoid the cytotoxic effects of $2-\mathrm{ME}_{2}$ observed at $\mu \mathrm{M}$ concentrations (Brueggemeier et al. 2001, Moobery 2003). We treated MCF-7 cells with $\mathrm{E}_{2}$, $16 \alpha-\mathrm{OHE}_{1}, 2-\mathrm{ME}_{2}$ or ICI 182,780 as single agents, or $\mathrm{E}_{2}$ or $16 \alpha-\mathrm{OHE}_{1}$ in combination with $2-\mathrm{ME}_{2}$ or ICI 182,780 for 24 and $48 \mathrm{~h}$. There was a significant increase in DNA synthesis by $\mathrm{E}_{2}$ and $16 \alpha-\mathrm{OHE}_{1}$ (Fig. 2). Our results also showed that $\mathrm{E}_{2}$-induced DNA synthesis was reduced from $500 \%$ to $200 \%$ at $24 \mathrm{~h}$ and from $400 \%$ to $200 \%$ at $48 \mathrm{~h}$ by $10 \mathrm{nM} 2-\mathrm{ME}_{2}$. Similarly, $16 \alpha-\mathrm{OHE}_{1}$-induced DNA synthesis was reduced from $650 \%$ to $270 \%$ at $24 \mathrm{~h}$ and from $500 \%$ to $250 \%$ at $48 \mathrm{~h}$ by $10 \mathrm{nM} 2-\mathrm{ME}_{2}$. The inhibitory effect of $2-\mathrm{ME}_{2}$ was lower than that of the pure antiestrogen, ICI 182,780, which reduced $\mathrm{E}_{2}$-induced DNA synthesis from $500 \%$ to $160 \%$ at $24 \mathrm{~h}$ and from $400 \%$ to $100 \%$ at $48 \mathrm{~h}$. These results indicate that $2-\mathrm{ME}_{2}$ can interfere with the 


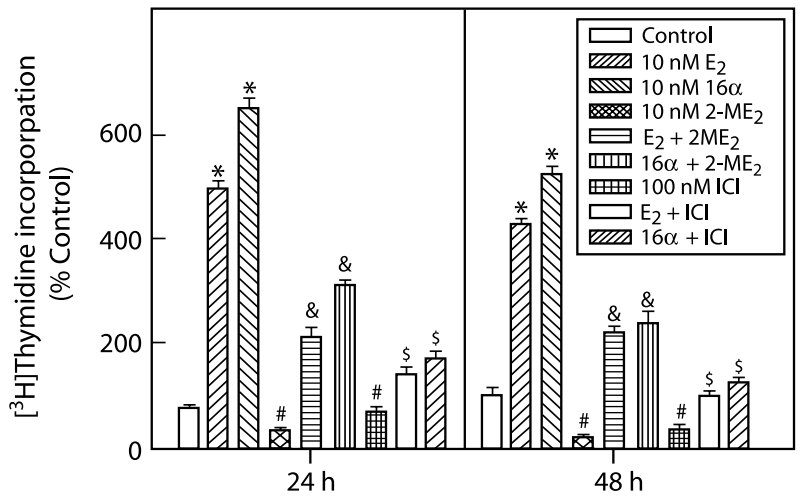

Figure 2 Effects of $\mathrm{E}_{2}, 16 \alpha-\mathrm{OHE}_{1}$ or $2-\mathrm{ME}_{2}$ on DNA synthesis of MCF-7 breast cancer cells. Cells $\left(0.5 \times 10^{6} /\right.$ dish) were treated with the indicated concentration of $\mathrm{E}_{2}, 16 \alpha-\mathrm{OHE}_{1}$ or $2-\mathrm{ME}_{2}$ for 24 and $48 \mathrm{~h}$. Results shown are the mean \pm S.E. from three separate experiments, and the $P$ values were determined by ANOVA followed by Dunnet's or Tukey's post-test.

*Significant stimulation compared with untreated control, $P<0.0001$; "significant inhibition compared with untreated control, $P<0.01 ;{ }^{\&}$ significant inhibition compared with $\mathrm{E}_{2}$ or $16 \alpha-\mathrm{OHE}_{1}$-treated cells, $P<0 \cdot 001$; $\$$ significant inhibition compared with $\mathrm{E}_{2}$ - or $16 \alpha-\mathrm{OHE}_{1}$-treated cells, $P<0.0001$. Fold induction was calculated by dividing the c.p.m. of treated cells by that of untreated control (average c.p.m. for control cells was $52,476 \pm 3007 ; n=3$ ).

growth-stimulatory effects of $\mathrm{E}_{2}$ and $16 \alpha-\mathrm{OHE}_{1}$ in MCF-7 cells.

We next examined the effect of this metabolite on cell cycle distribution by flow cytometry. Cells were treated with $\mathrm{E}_{2}, 16 \alpha-\mathrm{OHE}_{1}$ and $2-\mathrm{ME}_{2}$ as single agents or in combination, and the percent distribution of cells in different phases of the cell cycle was determined at
24- and 48-h time points by flow cytometry (Table 1). Treatment of cells with $\mathrm{E}_{2}$ and $16 \alpha-\mathrm{OHE}_{1}$ reduced the numbers of cells in the $\mathrm{G}_{1}$ phase from $77 \cdot 5 \%$ to $66 \cdot 4 \%$ and $65 \cdot 3 \%$ respectively, while increasing the numbers of cells in $\mathrm{S}$ phase from $11 \%$ to $22 \cdot 6 \%$ and $23 \cdot 3 \%$ respectively. In contrast, treatment of cells with $2-\mathrm{ME}_{2}$, as a single agent, did not have any significant effect on cell cycle distribution. However, 2-ME $\mathrm{ME}_{2}$ blocked the stimulatory effects of $\mathrm{E}_{2}$ and $16 \alpha-\mathrm{OHE}_{1}$ on $\mathrm{G}_{1}$ to $\mathrm{S}$ phase transition by $48 \mathrm{~h}$, yielding a cell cycle distribution similar to that of control cells.

\section{Effects of $E_{2}, 16 \alpha-\mathrm{OHE}_{1}$ and 2-ME $\mathrm{M}_{2}$ on cyclin D1 protein and cyclin D1 transactivation}

To investigate the mechanism by which $2-\mathrm{ME}_{2}$ inhibited $\mathrm{E}_{2}$ - and $16 \alpha-\mathrm{OHE}_{1}$-induced $\mathrm{G}_{1}$ to $\mathrm{S}$ phase progression of MCF-7 cells, we tested its effect on cyclin Dl protein levels. Cells were treated with $\mathrm{E}_{2}, 16 \alpha-\mathrm{OHE}_{1} 2-\mathrm{ME}_{2}$ or ICI 182,780 for $7 \mathrm{~h}$, and the cell lysate was analyzed by Western blotting. The 7-h time point was selected from our previous study showing the maximal induction of cyclin $\mathrm{D} 1$ by $\mathrm{E}_{2}$ and $16 \alpha-\mathrm{OHE}_{1}$ at $6-8 \mathrm{~h}$ (Lewis et al. 2001). There was a fourfold increase in cyclin D1 protein level by both $\mathrm{E}_{2}$ and $16 \alpha-\mathrm{OHE}_{1}$ at the 7 -h time point, compared with control (Fig. 3A). In contrast, there was no significant change in cyclin D1 protein level in cells treated with 4, 10 or $100 \mathrm{nM} 2-\mathrm{ME}_{2}$ compared with the control group. However, 2-ME was able to prevent the increase in cyclin $\mathrm{Dl}$ protein expression in the presence of $\mathrm{E}_{2}$ and $16 \alpha-\mathrm{OHE}_{1}$ (Fig. 3B). This effect was comparable to that produced by the pure antiestrogen, ICI 182,780 (Fig. 3B). Thus, a possible mechanism for the ability of $2-\mathrm{ME}_{2}$ to retard

Table 1 Percentage distribution of cells in different phases of cell cycle*.

\begin{tabular}{|c|c|c|c|c|c|c|}
\hline & $\mathrm{G}_{1}$ & s & $\mathrm{G}_{2} / \mathrm{M}$ & $G_{1}$ & $s$ & $\mathrm{G}_{2} / \mathrm{M}$ \\
\hline & $24 \mathrm{~h}$ & & & $48 \mathrm{~h}$ & & \\
\hline \multicolumn{7}{|l|}{ Treatment } \\
\hline None & $77 \cdot 5 \pm 1 \cdot 2$ & $10.9 \pm 0.5$ & $11 \cdot 6 \pm 0.6$ & $82 \cdot 3 \pm 2 \cdot 3$ & $6 \cdot 8 \pm 0 \cdot 6$ & $8 \cdot 3 \pm 0 \cdot 6$ \\
\hline $\mathrm{F}$ & $66.4 \pm 0.9$ & $22 \cdot 6 \pm 1 \cdot 3 \dagger$ & $10 \cdot 1 \pm 0.9$ & $68 \cdot 1 \pm 2 \cdot 1$ & $21.5 \pm 1 \cdot 1 \dagger$ & $10.4 \pm 0.5$ \\
\hline $16 \alpha-\mathrm{OHE}_{1}$ & $65 \cdot 3 \pm 1 \cdot 5$ & $23 \cdot 3 \pm 1 \cdot 7 \dagger$ & $11 \cdot 4 \pm 1 \cdot 4$ & $69 \cdot 7 \pm 1 \cdot 7$ & $21.3 \pm 0.5 \dagger$ & $9 \cdot 0 \pm 0.3$ \\
\hline $2-\mathrm{ME}_{2}$ & $76 \cdot 9 \pm 2 \cdot 7$ & $11.3 \pm 1.5$ & $11 \cdot 8 \pm 1 \cdot 1$ & $80 \cdot 4 \pm 1 \cdot 4$ & $10 \cdot 3 \pm 1 \cdot 2$ & $9 \cdot 0 \pm 1 \cdot 2$ \\
\hline $\mathrm{ICl} 182,780$ & $82 \cdot 3 \pm 1 \cdot 2$ & $8.4 \pm 0.4$ & $9 \cdot 3 \pm 0 \cdot 3$ & $81 \cdot 7 \pm 2 \cdot 1$ & $9 \cdot 1 \pm 0.4$ & $10 \cdot 2 \pm 1 \cdot 1$ \\
\hline $\mathrm{E}_{2}+2-\mathrm{ME}_{2}$ & $70.5 \pm 0.6$ & $14 \cdot 6 \pm 1 \cdot 2 \ddagger$ & $13 \cdot 9 \pm 0.7$ & $79 \cdot 3 \pm 1 \cdot 7$ & $11.5 \pm 1 \cdot 1$ & $9 \cdot 2 \pm 1 \cdot 3$ \\
\hline $16 \alpha-\mathrm{OHE}_{1}+2-\mathrm{ME}_{2}$ & $71 \cdot 8 \pm 1 \cdot 4$ & $15 \cdot 6 \pm 0.7 \ddagger$ & $13.6 \pm 0.5$ & $79 \cdot 2 \pm 2 \cdot 1$ & $11.4 \pm 1.4$ & $9 \cdot 4 \pm 1 \cdot 7$ \\
\hline$E_{2}+\mathrm{ICl} 182,780$ & $75 \cdot 1 \pm 0.7$ & $11 \cdot 2 \pm 0.3 \neq$ & $13 \cdot 7 \pm 0.8$ & $79 \cdot 9 \pm 1 \cdot 1$ & $9.1 \pm 0.3$ & $10 \cdot 1 \pm 0.5$ \\
\hline $16 \alpha+\mid \mathrm{Cl} 182,780$ & $74 \cdot 3 \pm 0 \cdot 6$ & $11 \cdot 7 \pm 0.6 \ddagger$ & $14 \cdot 1 \pm 1 \cdot 1$ & $78 \cdot 6 \pm 1 \cdot 4$ & $9.4 \pm 0.6$ & $10 \cdot 9 \pm 1 \cdot 2$ \\
\hline
\end{tabular}

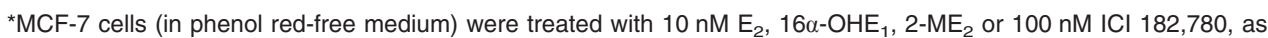
single agents, or in combination for 24 and $48 \mathrm{~h}$, and DNA was stained with propidium iodide and analyzed by flow cytometry. Percent distribution of cells in the different phases of the cell cycle was calculated with cytologic software program.

†Significantly different from control at $P<0.05$.

†Significantly different from $E_{2} / 16 \alpha$-treated cells, $P<0.05$.

Statistical difference between control and treated samples was determined by ANOVA followed by Dunnet's or Tukey's post-test. Results shown are the mean of three separate experiments \pm S.E. 
A

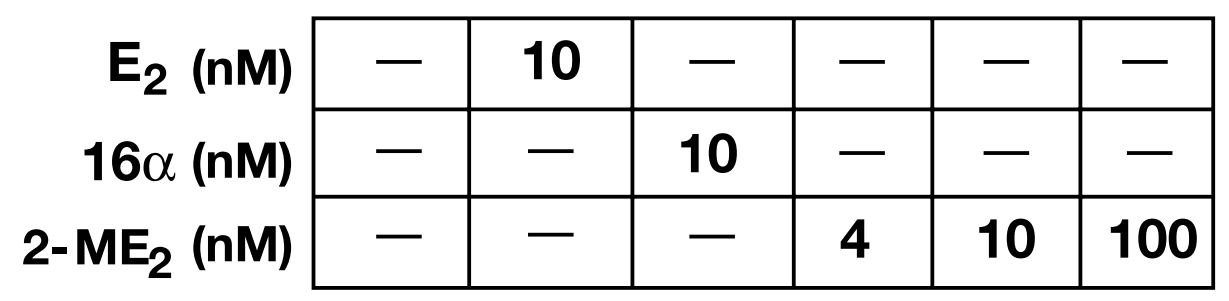

\section{Cyclin D1 -}

\section{$\beta$-actin -}

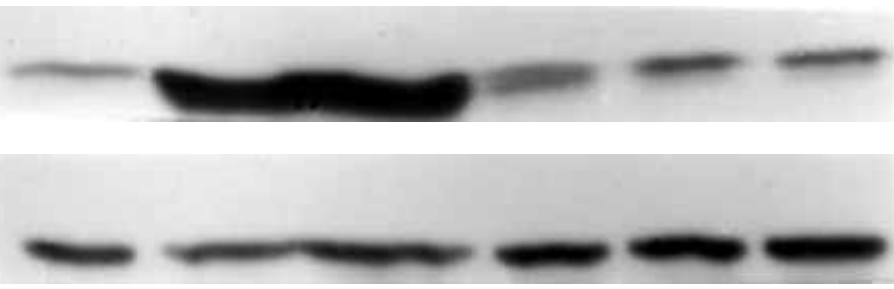

B

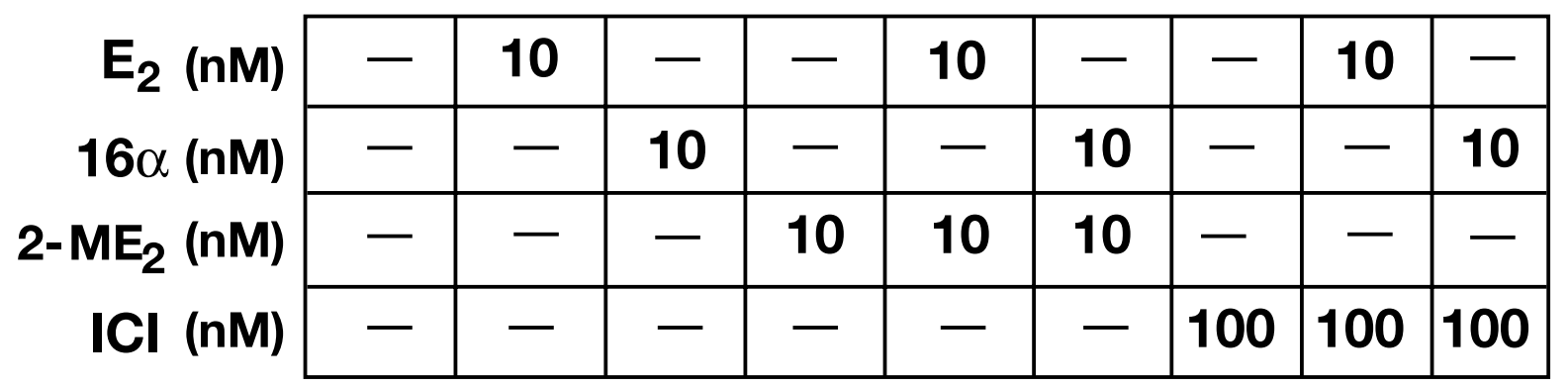

\section{Cyclin D1 -}

\section{$\beta$-actin -}

Figure 3 Western blot analysis of cyclin D1 in MCF-7 cells after treatment with $\mathrm{E}_{2}, 16 \alpha-\mathrm{OHE}_{1}$ or 2-ME $\mathrm{E}_{2}$. Cells were treated with $10 \mathrm{nM} \mathrm{E}_{2}$ or $16 \alpha-\mathrm{OHE}_{1}$, or 4, 10 and $100 \mathrm{nM} 2-\mathrm{ME}_{2}$ for $7 \mathrm{~h}(\mathrm{~A})$. The effect of $\mathrm{E}_{2}$ and $16 \alpha-\mathrm{OHE}_{1}$ on cyclin D1 expression in the presence of $2-\mathrm{ME}_{2}$ or ICI 182,780 is also shown (B). To verify equal protein loading and transfer, membranes were stripped and reprobed with anti- $\beta$-actin antibody. Results shown represent three separate experiments with comparable results.

cell-cycle progression mediated by $\mathrm{E}_{2}$ and $16 \alpha-\mathrm{OHE}_{1}$ might involve the suppression of cyclin D1.

We next examined the effects of $\mathrm{E}_{2}, 16 \alpha-\mathrm{OHE}_{1}$ and $2-\mathrm{ME}_{2}$ on cyclin $\mathrm{D} 1$ transactivation using a full-length cyclin D1 promoter plasmid (-1745CD1 LUC). Treatment of cells with either $\mathrm{E}_{2}$ or $16 \alpha-\mathrm{OHE}_{1}$ resulted in 7 - and 9.5-fold increases respectively in cyclin D1 promoter (-1745CD1 LUG) activity as compared with the control (Fig. 4A). 2-ME 2 alone did not show any significant effect on cyclin Dl transactivation. When combined with $\mathrm{E}_{2}$ or $16 \alpha-\mathrm{OHE}_{1}$, however, 2-ME significantly reduced the stimulatory effects of these compounds (Fig. 4A). ICI 182,780 also reduced cyclin D1 promoter activity induced by $\mathrm{E}_{2}$ and $16 \alpha-\mathrm{OHE}_{1}$ (Fig. 4A). These results indicate that $2-\mathrm{ME}_{2}$ can downregulate $\mathrm{E}_{2}$-induced transactivation of cyclin $\mathrm{D} 1$.

To test the functional importance of the CRE/ATF motif in cyclin $\mathrm{D} 1$ transactivation induced by $\mathrm{E}_{2}$ or $16 \alpha-\mathrm{OHE}_{1}$, we performed transfection experiments with a cyclin D1 promoter plasmid containing a mutated 

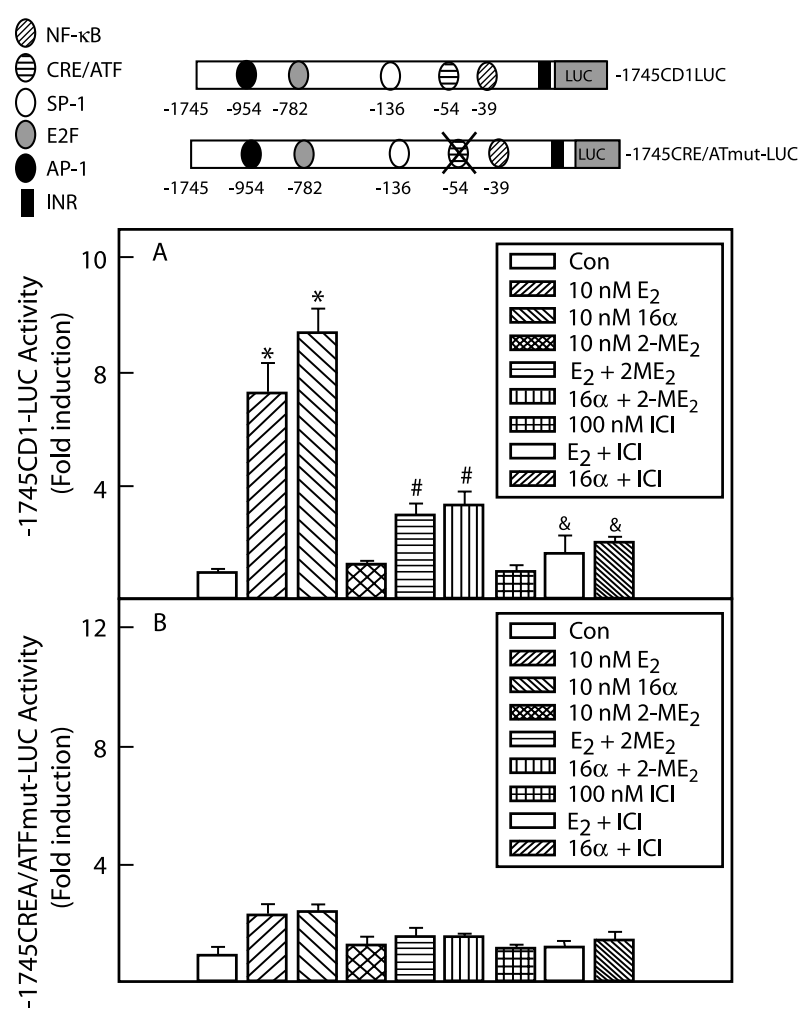

Figure 4 Effects of $\mathrm{E}_{2}, 16 \alpha-\mathrm{OHE}_{1}$ or $2-\mathrm{ME}_{2}$ on cyclin D1 promoter activity. MCF-7 cells $\left(1 \times 10^{5}\right.$ cells/dish) were cotransfected with a full-length cyclin D1 promoter plasmid (-1745CD1-LUC) and Renilla luciferase control plasmid. After $24 \mathrm{~h}$, cells were treated with $10 \mathrm{nM} \mathrm{E}_{2}, 16 \alpha-\mathrm{OHE}_{1}$ or $2-\mathrm{ME}_{2}$, as single agents, or $\mathrm{E}_{2}$ and $16 \alpha-\mathrm{OHE}_{1}$ in the presence of

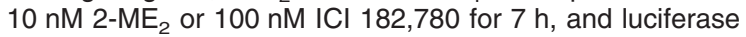
activity was measured. *Significantly different from untreated control cells at $P<0.0001$; "significantly different from $\mathrm{E}_{2} / 16 \alpha$-treated cells at $P<0.01$; \& significantly different from $\mathrm{E}_{2} / 16 \alpha$-treated cells at $P<0.001$. (B) Effect of ATF/CRE mutation on the activation of the full-length cyclin D1 promoter by $E_{2}$ and $16 \alpha-O H E_{1}$. These experiments were carried out essentially as described in (A), except that cells were transfected with a mutant cyclin D1 plasmid, -1745

CRE/ATFmut-LUC. Results are shown as the mean \pm S.E. of three separate transfection experiments.

CRE/ATF site (-1745 CRE/ATFmutLUC). Mutation of the CRE/ATF site significantly reduced cyclin D1 transactivation in the presence of $\mathrm{E}_{2}$ and $16 \alpha-\mathrm{OHE}_{1}$ (Fig. 4B), as compared with the wild-type plasmid. These results indicate that the CRE/ATF element is essential for the optimal induction of cyclin $\mathrm{Dl}$ by $\mathrm{E}_{2}$ and $16 \alpha-\mathrm{OHE}_{1}$.

To test the importance of the distal region of the cyclin $\mathrm{D} 1$ promoter in its transcriptional activation by $\mathrm{E}_{2}$ and $16 \alpha-\mathrm{OHE}_{1}$, we used a cyclin D1 promoter plasmid lacking regions -1745 to -964 (-963CD1 LUG). Our results (Fig. 5, upper panel, compared with Fig. 4A) showed that the removal of the distal region did not have a significant effect on cyclin D1 transcriptional
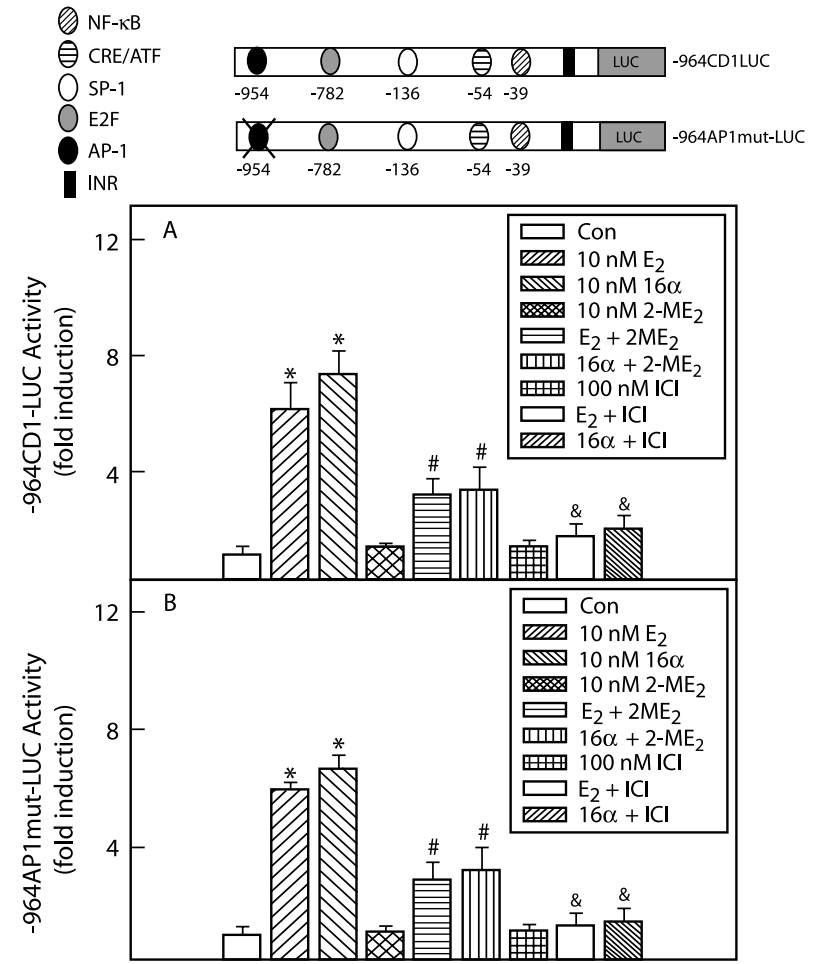

Figure 5 Transcriptional activation of the cyclin D1 promoter lacking the distal region. Cells were transfected with cyclin D1 promoter plasmid lacking regions -1745 to -964

(-964CD1-LUC) (upper panel) or a plasmid (-964AP1CD1-LUC) with mutation at the AP1 site (lower panel) and the control Renilla luciferase plasmid. Subsequently, cells were treated with $\mathrm{E}_{2}$ or $16 \alpha-\mathrm{OHE}_{1}$ in the absence or presence of $2-\mathrm{ME}_{2}$ or ICI 182,780 for $7 \mathrm{~h}$. * Significantly different from untreated control cells at $P<0.0001$; "significantly different from $\mathrm{E}_{2} / 16 \alpha$-treated cells at $P<0.01$; \& significantly different from $\mathrm{E}_{2} / 16 \alpha$-treated cells at $P<0.001$. The results are shown as the mean \pm S.E. of three separate transfection experiments.

activation by $\mathrm{E}_{2}$ or $16 \alpha-\mathrm{OHE}_{1}$. Furthermore, mutation of the AP-1 site had no marked effect on the induction of cyclin $\mathrm{D} 1$ by $\mathrm{E}_{2}$ or $16 \alpha-\mathrm{OHE}_{1}$ (Fig. 5 , lower panel).

To confirm the role of the CRE/ATF site in the regulation of cyclin $\mathrm{D} 1$ promoter activity, we transfected MCF-7 cells with a -66 cyclin D1 promoter containing a GRE/ATF and NF- $\mathrm{KB}$ site (-66CD1 LUG). Our results showed that transactivation of the -66CD1 LUC promoter increased by sixfold in the presence of $\mathrm{E}_{2}$ and by $7 \cdot 5$-fold in the presence of $16 \alpha-\mathrm{OHE}_{1}$, and this induction was significantly inhibited (four- to fivefold) by ICI 182,780 and $2-\mathrm{ME}_{2}$ (Fig. 6A). Mutation of the CRE/ATF site on the cyclin D1 promoter (-66 GRE/ATFmutLUG) resulted in $\sim 70 \%$ decrease in transactivation, as compared with the wild-type plasmid (-66CD1 LUG) (Fig. 6B). Interestingly, mutation of the NF- $\kappa \mathrm{B}$ site did not significantly reduce cyclin D1 promoter activity induced by $\mathrm{E}_{2}$ or $16 \alpha-\mathrm{OHE}_{1}$ (Fig. $6 \mathrm{C}$ ). 
A
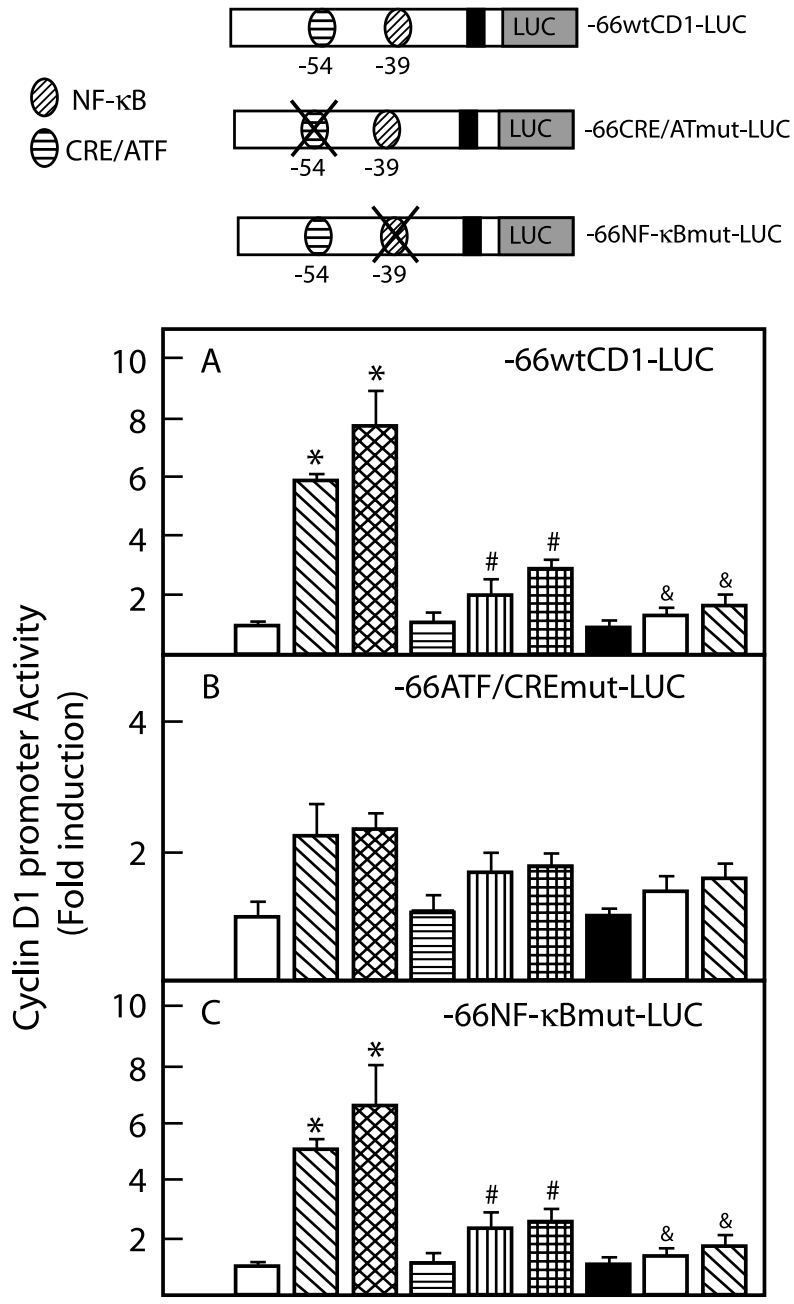

\begin{tabular}{|r|c|c|c|c|c|c|c|c|c|}
\hline $10 \mathrm{nM} \mathrm{E}_{2}$ & - & + & - & - & + & - & - & + & - \\
\hline $10 \mathrm{nM} 16 \alpha$ & - & - & + & - & - & + & - & - & + \\
\hline $10 \mathrm{nM} 2-\mathrm{ME}_{2}$ & - & - & - & + & + & + & - & - & - \\
\hline $100 \mathrm{nM} \mathrm{ICl}$ & - & - & - & - & - & - & + & + & + \\
\hline
\end{tabular}

Figure 6 Transcriptional activation of the truncated cyclin D1 promoter by $\mathrm{E}_{2}$ and $16 \alpha-\mathrm{OHE}_{1}$. (A) Cells $\left(1 \times 10^{5}\right.$ per dish) were cotransfected with the cyclin D1 promoter (-66CD1 Luc) and

Renilla luciferase control plasmid. Cells were treated with $\mathrm{E}_{2}$ or $16 \alpha-\mathrm{OHE}_{1}$ in the absence or presence of $2-\mathrm{ME}_{2}$ or ICI 182,780 for $7 \mathrm{~h}$. (B) Truncated cyclin D1 promoter with ATF/CRE mutation was used for transfection. (C) Truncated cyclin promoter with NF-kB site mutation was used for transfection. *Significantly different from untreated control cells at $P<0.0001$; "significantly different from $\mathrm{E}_{2} / 16 \alpha$-treated cells at

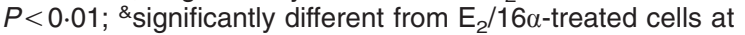
$P<0.001$. The results are shown as the mean \pm S.E. of three separate transfection experiments.

\begin{tabular}{r|c|c|c|c|c|c|c|}
$\mathrm{E}_{2}(\mathrm{nM})$ & - & 10 & - & - & 10 & - & - \\
\cline { 2 - 8 } $16 \alpha(\mathrm{nM})$ & - & - & 10 & - & - & 10 & - \\
\cline { 2 - 8 } $2-\mathrm{ME}_{\mathbf{2}}(\mathrm{nM})$ & - & - & - & 10 & 10 & 10 & - \\
\cline { 2 - 8 } $\mathrm{ICI}(\mathrm{nM})$ & - & - & - & - & - & - & 100 \\
\cline { 2 - 7 } & & & & &
\end{tabular}

ATF-2 -

B

\begin{tabular}{r|c|c|c|c|c|c|}
$E_{2}(n M)$ & - & 10 & - & - & 10 & - \\
\cline { 2 - 7 } $16 \alpha(n M)$ & - & - & 10 & - & - & 10 \\
\cline { 2 - 7 } ICI (nM) & - & - & - & 100 & 100 & 100 \\
\cline { 2 - 6 } & & &
\end{tabular}

ATF-2 -

C

\begin{tabular}{r|c|c|c|c|c|c|c|}
$\mathrm{E}_{2}(\mathrm{nM})$ & - & 10 & - & - & 10 & - & - \\
\cline { 2 - 8 } $16 \alpha(\mathrm{nM})$ & - & - & 10 & - & - & 10 & - \\
\cline { 2 - 8 } $2-\mathrm{ME}_{2}(\mathrm{nM})$ & - & - & - & 10 & 10 & 10 & - \\
\cline { 2 - 8 } $\mathrm{ICI}_{(\mathrm{nM})}$ & - & - & - & - & - & - & 100 \\
\cline { 2 - 8 } & & &
\end{tabular}

Phospho-ATF-2 -

Figure 7 ATF-2 binding to the CRE/ATF site of cyclin D1 in the presence of $\mathrm{E}_{2}, 16 \alpha-\mathrm{OHE}_{1}, 2-\mathrm{ME}_{2}$ or ICI 182,780 . MCF-7 cells $\left(2.5 \times 10^{6}\right.$ cells/dish) were treated with $10 \mathrm{nM} \mathrm{E}_{2}, 16 \alpha-\mathrm{OHE}_{1}$ and $2-\mathrm{ME}_{2}$ for $7 \mathrm{~h}$. Cellular extracts were incubated with ODN1 for $1 \mathrm{~h}$ at $4{ }^{\circ} \mathrm{C}$. The DNA-bound proteins were separated on a $10 \%$ SDS-PAGE and identified by immunoblotting with antibodies specific for ATF-2 and phosphorylated ATF-2 (phospho-ATF-2). (A) Effect of 2-ME $\mathrm{M}_{2}$ on $\mathrm{E}_{2}$ and $16 \alpha-\mathrm{OHE}_{1}$-mediated increase in ATF-2 binding to cyclin D1 promoter. (B) Effect of $\mathrm{ICl} 182,270$ on $\mathrm{E}_{2}$ and

$16 \alpha-\mathrm{OHE}_{1}$-mediated increase in ATF-2 binding to cyclin D1 promoter. (C) Effect of $2-\mathrm{ME}_{2}$ on $\mathrm{E}_{2}$ and $16 \alpha-\mathrm{OHE}_{1}$-mediated increase in phospho-ATF-2 binding to cyclin D1 promoter. The results presented here represent three separate experiments.

\section{Effects of $E_{2}, 16 \alpha-O H E_{1}$ and 2-ME $E_{2}$ on ATF-2 binding to CRE/ATF element}

In this series of experiments, we examined the effects of $\mathrm{E}_{2}, 16 \alpha-\mathrm{OHE}_{1}$ and $2-\mathrm{ME}_{2}$ on the binding of ATF-2 to a 74-mer ODN1 from cyclin Dl promoter. Cells were treated with $10 \mathrm{nM} \mathrm{E} \mathrm{E}_{2}, 16 \alpha-\mathrm{OHE}_{1}$ or $2-\mathrm{ME}_{2}$, as single agents, or $\mathrm{E}_{2}$ and $2-\mathrm{ME}_{2}$ combinations for $7 \mathrm{~h}$. A cellular extract was prepared, and binding to ODN1 determined by DNA affinity assay. (The specificity of the assay was verified with a mutant 74-mer ODN with a 3 base pair mutation at the ATF-2 binding site.) Figure 7 shows our results from DNA affinity assay with the wild-type 74-mer ODN. There was very little constitutive binding of ATF-2 to ODNl in the absence of treatment. Treatment of cells with $\mathrm{E}_{2}$ resulted in a twoto threefold increase $(n=3)$ in ATF-2 binding to ODN1, while $16 \alpha-\mathrm{OHE}_{1}$ caused a fourfold increase $(n=3)$ (Fig. 7). In contrast, treatment of cells with $2-\mathrm{ME}_{2}$ resulted in a relatively minor band of ATF-2 binding. Importantly, 2-ME $\mathrm{E}_{2}$ blocked the effects of both $\mathrm{E}_{2}$ 


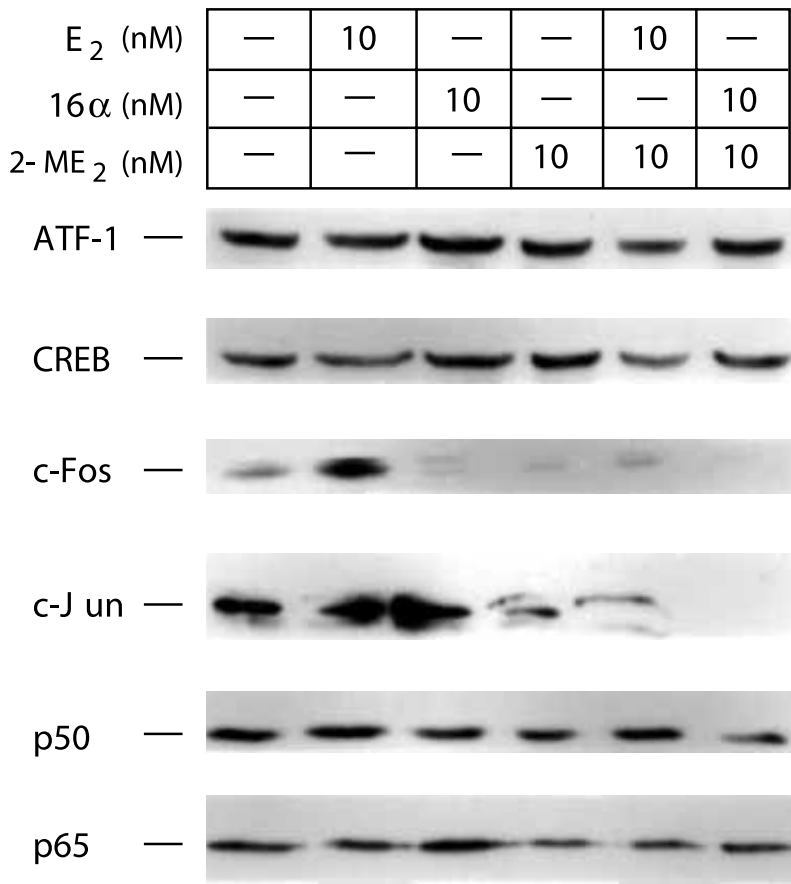

Figure 8 Binding of ATF-1, CREB, AP-1 and NF- $\mathrm{B} B$ proteins to the cyclin D1 CRE/ATF site. MCF-7 cells $\left(2.5 \times 10^{6}\right.$ cells/dish) were treated with $\mathrm{E}_{2}, 16 \alpha-\mathrm{OHE} \mathrm{E}_{1}$ or $2-\mathrm{ME}_{2}$ for $7 \mathrm{~h}$, and cellular extract was incubated with ODN $1(1 \mu \mathrm{M})$ for $1 \mathrm{~h}$ at $4{ }^{\circ} \mathrm{C}$. The DNA-bound proteins were separated on a $10 \%$

SDS-polyacrylamide gel and identified by immunoblotting with antibodies specific for ATF-1, CREB, c-Jun, c-Fos, p50 and p65. The results shown represent three separate binding experiments.

and $16 \alpha-\mathrm{OHE}_{1}$ treatment on ATF-2 binding to ODN1 (Fig. 7A). This inhibitory effect was similar to that observed with ICI 182,780 (Fig. 7B). To verify that the increase in ATF-2 binding was due to phosphorylation, membrane (Fig. 7A) was stripped and reblotted with a phospho-ATF-2 specific antibody. The binding of phosphorylated ATF-2 to ODN1 was increased by $2 \cdot 5$-fold in the presence of $\mathrm{E}_{2}$ and by fourfold in the presence of $16 \alpha-\mathrm{OHE}_{1}$, compared with control cells. In the presence of $2-\mathrm{ME}_{2}$, the effects of $\mathrm{E}_{2}$ and $16 \alpha-\mathrm{OHE}_{1}$ were significantly reduced (Fig. 7C). These results show that both $\mathrm{E}_{2}$ and $16 \alpha-\mathrm{OHE}_{1}$ enhanced the DNAbinding activity of ATF-2 through its phosphorylation, and that $2-\mathrm{ME}_{2}$ downregulated this process.

We also examined the DNA-binding activity of c-Jun, c-Fos, ATF-1, CREB and NF-кB-p65/p50 in MCF-7 cells to test the effects of $\mathrm{E}_{2}, 16 \alpha-\mathrm{OHE}_{1}$ and $2-\mathrm{ME}_{2}$. Our results showed that these transcription factors bound to ODN1 constitutively; however, c-Jun and c-Fos binding was altered by $\mathrm{E}_{2}$ or $16 \alpha-\mathrm{OHE}_{1}$ treatment (Fig. 8). With $\mathrm{E}_{2}$, binding of c-Fos and c-Jun to ODN1 increased by 2and $1 \cdot 3$-fold respectively, whereas with $16 \alpha-\mathrm{OHE}_{1}$ the binding of c-Jun increased by twofold over the control.

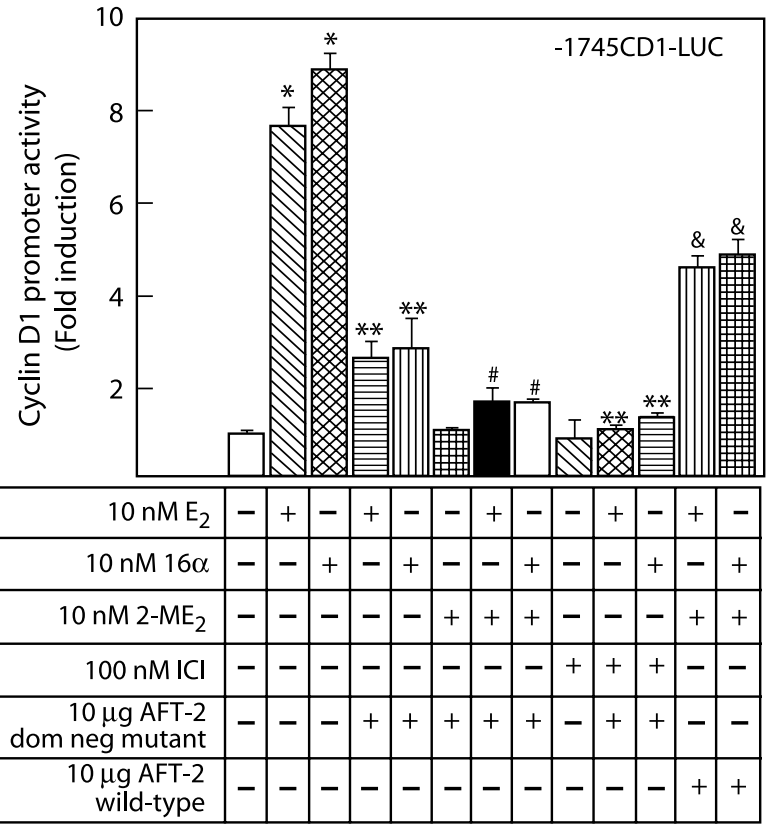

Figure 9 Effect of ATF-2 dominant negative mutant (dom neg mut) on $E_{2}$ and $16 \alpha-\mathrm{OHE}_{1}$-stimulated cyclin D1 transactivation. MCF-7 cells were cotransfected with the full-length cyclin D1 luciferase reporter plasmid (-1745CD1-LUC), $10 \mu \mathrm{g}$ expression vector for ATF-2 dominant negative mutant or ATF-2 wild-type, and Renilla luciferase control. Cells were treated with $10 \mathrm{nM}$ $\mathrm{E}_{2}, 16 \alpha-\mathrm{OHE}_{1}$ or $2-\mathrm{ME}_{2}$ as separate agents or in combination for $7 \mathrm{~h}$, and luciferase activity was determined. The results shown are the mean \pm S.E. of three separate experiments. *Significant $(P<0.0001)$ induction compared with untreated control; **significant inhibition compared with $\mathrm{E}_{2} / 16 \alpha$ treatment groups $(P<0.001)$; " significantly different from $\mathrm{E}_{2} / 16 \alpha-\mathrm{OHE}_{1}$ and ATF-2 (dom neg mut) treated cells $(P<0.05)$; \& significantly different from $\mathrm{E}_{2} / 16 \alpha$-treated cells $(P<0.01)$.

Treatment with $2-\mathrm{ME}_{2}$, as a single agent, or in combination with $\mathrm{E}_{2}$ or $16 \alpha-\mathrm{OHE}_{1}$, caused a significant reduction of both c-Fos and c-Jun binding to ODN1.

\section{Effect of ATF-2 dominant negative mutant on cyclin D1 transactivation}

We next performed transfection studies using an ATF-2 dominant negative mutant to verify the importance of ATF-2 protein in cyclin D1 activation. Cells were transfected with the full-length cyclin D1 reporter plasmid along with dominant negative mutant expression vector. After transfection, cells were treated with $10 \mathrm{nM} \mathrm{E} \mathrm{E}_{2}$ or $16 \alpha-\mathrm{OHE}_{1}$ in the presence or absence of $2-\mathrm{ME}_{2}$ for $7 \mathrm{~h}$, and cyclin D1 luciferase activity was measured. Our results (Fig. 9) showed that transfection of cells with the ATF-2 dominant negative mutant resulted in a significant reduction (four- to sixfold) of $\mathrm{E}_{2}$ and $16 \alpha-\mathrm{OHE}_{1}$-induced cyclin Dl transactivation. ATF-2 dominant negative mutant in the presence of 


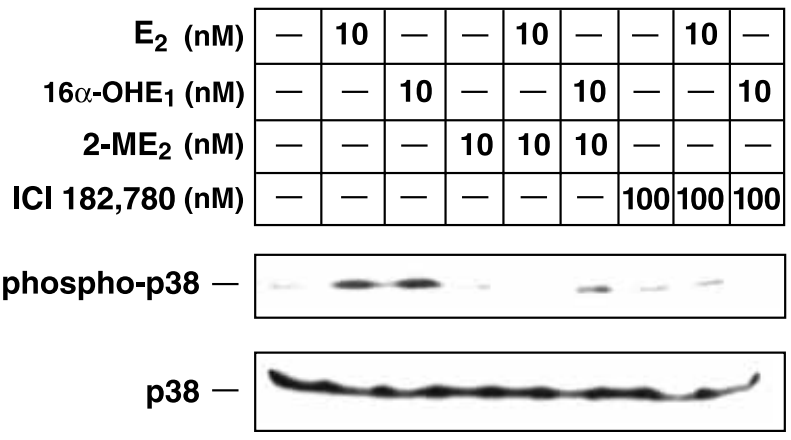

Figure 10 Effects of $\mathrm{E}_{2}, 16 \alpha-\mathrm{OHE}_{1}$ and $2-\mathrm{ME}_{2}$ on p38 MAP kinase activity in MCF-7 breast cancer cells. MCF-7 cells $\left(2.5 \times 10^{6}\right.$ cells/dish) were treated with $10 \mathrm{nM} \mathrm{E}_{2}$ or $16 \alpha-\mathrm{OHE}_{1}$ in the presence or absence of $10 \mathrm{nM} 2-\mathrm{ME}_{2}$ or $100 \mathrm{nM} \mathrm{ICl}$ 182,780 for $7 \mathrm{~h}$. Cells were then lysed, and active p38 MAP kinase (phospho-p38) was detected by immunoblotting. To ensure equal protein loading, the membrane was stripped and reprobed for total p38 MAP kinase. The result presented here represents three separate experiments.

2-ME $\mathrm{M}_{2}$ further suppressed cyclin D1 promoter activity. In contrast, overexpression of the ATF-2 wild-type protein partially reversed the inhibitory effects of $2-\mathrm{ME}_{2}$ on cyclin D1 transactivation, confirming the importance of ATF-2 in the action of $2-\mathrm{ME}_{2}$.

\section{Effects of $E_{2}$ and its metabolites on p38 MAPK activation in MCF-7 cells}

ATF-2 is activated by phosphorylation, in part, by p38 MAPK (Waas et al. 2001, Recio et al. 2002). We therefore examined phosphorylation of p38 MAPK in MCF-7 cells. Cells were treated with $10 \mathrm{nM} \mathrm{E} \mathrm{E}_{2}$ or $16 \alpha-\mathrm{OHE}_{1}$, in the presence or absence of $10 \mathrm{nM} 2-\mathrm{ME}_{2}$ or $100 \mathrm{nM}$ ICI 182,780 , and p38 MAPK was detected by Western blotting. Our results (Fig. 10) show that $\mathrm{E}_{2}$ or $16 \alpha-\mathrm{OHE}_{1}$ caused a threefold increase in the level of phospho-p38 MAPK as compared with the control. In contrast, $2-\mathrm{ME}_{2}$ when combined with $\mathrm{E}_{2}$ or $16 \alpha-\mathrm{OHE}_{1}$, significantly reduced the level of phospho-p38 MAPK. ICI 182,780 also significantly reduced the effect of $\mathrm{E}_{2}$ and $16 \alpha-\mathrm{OHE}_{1}$ on phospho-p38 levels (Fig. 10). These results indicate that $\mathrm{E}_{2}$ and its metabolites altered p38 MAPK activity, and suggest a mechanism for the activation of ATF-2.

\section{Discussion}

In this report, we present evidence for the growthinhibitory effect of low concentrations of $2-\mathrm{ME}_{2}$ on MCF-7 breast cancer cells. We found that $\mathrm{E}_{2}$ and $16 \alpha-\mathrm{OHE}_{1}$ significantly enhanced cyclin $\mathrm{Dl}$ protein level compared with the control. Transient transfection experiments, using a full-length cyclin D1 promoter construct, show that $\mathrm{E}_{2}$ and $16 \alpha-\mathrm{OHE}_{1}$ increased cyclin D1 promoter activity by $7 \cdot 5$ - and $9 \cdot 5$-fold respectively, whereas $2-\mathrm{ME}_{2}$ reduced the stimulatory effects of these compounds. Our results also show that transactivation of cyclin $\mathrm{D} 1$ by $\mathrm{E}_{2}$ and $16 \alpha-\mathrm{OHE}_{1}$ is mediated by the GRE/ATF motif. $\mathrm{E}_{2}$ and $16 \alpha-\mathrm{OHE}_{1}$ facilitated the binding of ATF-2 to the CRE/ATF motif. Increase in DNA binding of ATF-2 was associated with phosphorylation of ATF-2 and p38 MAPK, events that were significantly inhibited by $2-\mathrm{ME}_{2}$ and ICI 182,780 . These results indicate that estrogenic induction of cyclin D1 transcription involves the p38 phosphorylation cascade that is inhibited by $2-\mathrm{ME}_{2}$.

$\mathrm{E}_{2}$ was shown to upregulate the levels of cyclin D1 at the mRNA and protein levels along with other critical mediators of cell cycle progression (Altucci et al. 1996, 1997, Foster \& Wimalasena 1996, Prall et al. 1997, Doisneau-Sixou et al. 2003). Although $\mathrm{E}_{2}$-induced regulation of cyclin D1 transcription has been established by these and other studies, the molecular mechanism or mechanisms are complex and poorly defined (Planas-Silva et al. 1999, Sabbah et al. 1999, Foster et al. 2001). It is important to note that the cyclin D1 promoter does not contain an ERE element; however, it contains regulatory elements for ATF-2, AP-1, CREB, NF-אB, E2F and SP-1, all of which have been shown to regulate its gene expression (Pestell et al. 1999, Sutherland \& Musgrove 2004).

We found that the CRE/ATF site, located at position -54 from the transcriptional start site of the cyclin D1 promoter was required for the induction of cyclin D1 by $\mathrm{E}_{2}$ and $16 \alpha-\mathrm{OHE}_{1}$. Mutation of this site led to a dramatic reduction (60-80\%) in the cyclin D1 promoter activity induced by these agents (Figs $4 \mathrm{~B}$ and $6 \mathrm{~B}$ ). The marked increase in the DNA binding of ATF-2 in the presence of $\mathrm{E}_{2}$ and $16 \alpha-\mathrm{OHE}_{1}$ and its inhibition by 2-ME $\mathrm{M}_{2}$ support the role of GRE/ATF-2 site. However, there was about a twofold induction of cyclin D1 promoter activity in ATF/CRE mutant constructs in the presence of $\mathrm{E}_{2}$. The low level of promoter activity in ATF/CREMUT constructs could be attributed to the binding of AP-1 proteins through consensus or AP-1-like elements. Increased binding of c-Jun and c-Fos to the cyclin D1 promoter fragment supports the role of AP-1 proteins in $\mathrm{E}_{2}$-induced cyclin $\mathrm{D} 1$ transactivation. In contrast, the binding of ATF-1, CREB or NF- $\kappa \mathrm{B}$ proteins to the cyclin $\mathrm{D} 1$ promoter fragment did not show any change in the presence of $\mathrm{E}_{2}, 16 \alpha-\mathrm{OHE}_{1}$ or $2-\mathrm{ME}_{2}$. These results are consistent with previous reports on the roles of the $\mathrm{CRE} / \mathrm{ATF}$ and $\mathrm{AP}-1$ sites in cyclin D1 gene activation (Brown et al. 1998, Beier et al. 1999, Lee et al. 1999, Liu et al. 2002). However, mutation of the AP-1 site, while retaining the ATF/CRE site, did not affect cyclin D1 promoter activity. The ability of ATF/CREB proteins to form selective heterodimers with AP-1 proteins (Uht et al. 1997, 
Chinenov \& Kerppola 2001), the presence of AP-1-like elements (GACTA versus the consensus AP-1 element TGACTAA) close to the ATF/CRE site and the ability of ER $\alpha$ to interact with the Jun protein (Teyssier et al. 2001) might be important factors in the flexibility of the cyclin D1 transcriptional response.

ICI 182,780 could inhibit cyclin D1 promoter activity induced by $\mathrm{E}_{2}$ and $16 \alpha-\mathrm{OHE}_{1}$, suggesting that activation of cyclin D1 involves the function of the ER. ICI 182,780 is able to inhibit nongenomic action of $\mathrm{E}_{2}$, such as the activation of the phosphorylation cascade (Wade et al. 2001, Kinoshita \& Chen 2003). ICI 182,780 binding of $\mathrm{ER} \alpha$ provides it with a unique conformational state, interrupting protein-protein associations (Weatherman et al. 2002, Margeat et al. 2003). In addition, ligand-induced alterations in signaling pathways determine the availability and homo/heterodimer formation between ATF-2, c-Jun and c-Fos, leading to their binding to the CRE/ATF motif of the cyclin D1 promoter. The formation of these multiprotein complexes and their DNA binding appears to be facilitated by the presence of $\mathrm{E}_{2}$ and $16 \alpha-\mathrm{OHE}_{1}$, but disrupted by $2-\mathrm{ME}_{2}$ and ICI 182,780.

While the ability of $2-\mathrm{ME}_{2}$ to inhibit $\mathrm{E}_{2}$-induced growth stimulation suggests that it might be functioning like an antiestrogen, $2-\mathrm{ME}_{2}$ does not have the properties of ICI 182,780 or other antiestrogens. 2-ME 2 has very low binding affinity for ER $\left(\sim 1 \%\right.$ that of $\mathrm{E}_{2}$ ) (Dubey et al. 2000, Brueggemeier et al. 2001) and inhibits both ER-positive and ER-negative tumor growth (Robertson 2001, Schumacher \& Neuhaus 2001). However, binding affinity does not always correlate with biologic activity. Previous studies have indicated that $16 \alpha-\mathrm{OHE}_{1}$ binds to the classical $\mathrm{ER} \alpha$ with an affinity $\sim 10 \%$ of that of $\mathrm{E}_{2}$; however, it is as potent as $\mathrm{E}_{2}$ in stimulating uterine growth (Suto et al. 1999). 16 $\alpha$-OHE ${ }_{1}$ was slightly more potent than $\mathrm{E}_{2}$ in stimulating DNA synthesis, cell cycle progression and cyclin D1 expression in MCF-7 cells (Lewis et al. 2001). Hence, the antiestrogenic effects of $2-\mathrm{ME}_{2}$ might not be dependent on its high affinity binding to the classical ER. Alternatively, as suggested by Kousteini et al. (2001), the classical binding assays may not capture the efficiency of ligand association rates, but rather the ratio of association to dissociation rates.

It is also possible that $2-\mathrm{ME}_{2}$ may utilize a receptor that is distinct from the classical ER. Potential receptors include: 1. the type II ER (Markaverich \& Clark 1987, Shoulars et al. 2002); 2. one or more of the variants of $\mathrm{ER} \alpha$ or $\operatorname{ER} \beta$ (Fuqua et al. 1991) and 3. certain members of the nuclear orphan receptor family (Laudet et al. 1992). Plasma membrane ER that mediates rapid activation of signaling pathways in response to $E_{2}$ is found in target cells (Migliaccio et al. 1996, Falkenstein et al. 2000, Kousteni et al. 2001). Although plasma membrane ER is reported to be similar to the classical nuclear ER $\alpha$, unique ligand specificity might exist due to ER association with scaffold proteins, such as caveolin (Razandi et al. 1999, Marquez \& Pietras 2001, Song et al. 2004). Therefore, $\mathrm{E}_{2}$ and $16 \alpha-\mathrm{OHE}_{1}$ can utilize a number of signaling pathways other than the classical ER pathway to stimulate the transcription of cyclin D1. The mechanism of $2-\mathrm{ME}_{2}$ in antagonizing the effects of $\mathrm{E}_{2}$ appears to involve a blockade of estrogenic signaling through p38 MAPK and ATF-2 phosphorylation.

ATF-2 is phosphorylated by JNK/SAPK and p38 MAP kinases, in response to cellular stress (van Dam et al. 1995, Raingeaud et al. 1996), and by extracellular signal-regulated kinases (ERK), in response to growth factors (Albanese et al. 1995, Watanabe et al. 1996). Phosphorylation of ATF-2 increases its transcriptional activity by relieving intramolecular inhibitory interaction between the DNA-binding domain and the transactivating domain (Abdel-Hafiz et al. 1992, Kawasaki et al. 2000). In our experiments, increased ATF-2 binding to DNA was facilitated by ATF-2 phosphorylation and associated cyclin D1 transcriptional activation. Activation of p38 MAPK appears to be responsible for ATF-2 phosphorylation, since a three- to fourfold higher level of phosphorylated p38 MAPK is found in cells treated with $\mathrm{E}_{2}$ and $16 \alpha-\mathrm{OHE}_{1}$ than in control cells. 2- $\mathrm{ME}_{2}$ blocked the stimulatory effects of $\mathrm{E}_{2}$ and $16 \alpha-\mathrm{OHE}_{1}$ on ATF-2 phosphorylation and cyclin D1 promoter activation. The inhibitory effect of $2-\mathrm{ME}_{2}$ might be due to reduced phosphorylation of p38 MAPK. However, it is not known what step of the signaling cascade, leading to the phosphorylation of p38 MAPK, is inhibited by $2-\mathrm{ME}_{2}$.

Activation of p38 MAPK might be mediated by nongenomic action of estrogens. Recent studies reveal many instances of estrogenic action with activation of Src/Shc/ERK signaling pathways by ER $\alpha$ located on membrane sites of target cells (Castoria et al. 2001, Kousteni et al. 2001, Song et al. 2002, 2004). Estrogenic action may include ER interaction with the $G$ protein-coupled receptor, GPCR30, which stimulates adenylyl cyclase activity, leading to the production of cAMP and associated signaling (Aronica et al. 1994, Filardo et al. 2002). Alternatively, $\mathrm{E}_{2}$ stimulation of MCF-7 cells may induce a direct interaction between $\mathrm{ER} \alpha, \mathrm{Src}$ and the p85 subunit of phosphatidylinositol (PI)3-kinase, thereby activating the PI3K/Akt pathway (Migliaccio et al. 1996). In another study, the HER-2 signaling pathway was implicated in $\mathrm{E}_{2}$-induced activation of Akt (Stoica et al. 2003). Akt may activate p38 MAPK (Madrid et al. 2001). Further studies are needed to validate the involvement of these pathways in the activation of p38 MAPK by $\mathrm{E}_{2}$.

Previous studies indicated that $2-\mathrm{ME}_{2}$ inhibits DNA synthesis in MCF-7 and MDA-MB-231 breast cancer cells (Seegers et al. 1989, Brueggemeier et al. 2001, Schumacher \& Neuhaus 2001). In human prostate 
cancer, 2-ME $\mathrm{ME}_{2}$ inhibited tumor growth by arresting cells in the $\mathrm{G}_{2} / \mathrm{M}$ phase of the cell cycle (Kumar et al. 2001). The 2- $\mathrm{ME}_{2}$-induced $\mathrm{G}_{2} / \mathrm{M}$ block, occurring at $3 \mu \mathrm{M}$ concentration, was associated with a significant increase in p21 and cdc2 expression. An effect of $2-\mathrm{ME}_{2}$ on tubulin polymerization has been reported at $3 \mu \mathrm{M}$ or higher concentration (Cushman et al. 1995, Klauber et al. 1997, Pribluda et al. 2000). In the osteosarcoma 143 B cell line, a dual effect of $2-\mathrm{ME}_{2}$ on cell cycle was observed with $\mathrm{G}_{1}$ arrest at $1 \mu \mathrm{M}$ level and $\mathrm{G}_{2} / \mathrm{M}$ arrest at $10 \mu \mathrm{M}$ level (Golebiewska et al. 2002). We found that $2-\mathrm{ME}_{2}$ is effective in blocking the stimulatory effects of $\mathrm{E}_{2}$ and $16 \alpha-\mathrm{OHE}_{1}$ on DNA synthesis, and $\mathrm{G}_{1}$ to $\mathrm{S}$ phase progression. The increased expression of cyclin D1 caused by $\mathrm{E}_{2}$ and $16 \alpha-\mathrm{OHE}_{1}$ is downregulated by $2-\mathrm{ME}_{2}$. In the absence of $\mathrm{E}_{2}$, the low level of DNA synthesis found in phenol red-free cells is inhibited by $2-\mathrm{ME}_{2}$, although this was not sufficient to be detected as a cell cycle arrest by flow cytometry. Thus, in the absence of $\mathrm{E}_{2}, \mathrm{MCF}-7$ cells remain largely $(77-82 \%)$ in the $G_{1}$ phase in the presence or absence of low concentrations of $2-\mathrm{ME}_{2}$. This may be because breast cancer cells with low growth fraction are more resistant to the action of antiproliferative agents than log-phase cells (Carlisle et al. 2002).

In summary, our results show that $\mathrm{E}_{2}$ and $16 \alpha-\mathrm{OHE}_{1}$ stimulate cell growth and cell cycle progression by upregulating cyclin $\mathrm{D} 1$ expression, whereas $2-\mathrm{ME}_{2}$, like an antiestrogen, blocks the stimulatory effects of $\mathrm{E}_{2}$ and $16 \alpha-\mathrm{OHE}_{1}$. Estrogenic regulation of the cyclin D1 gene occurs at the transcriptional level and is mediated by the CRE/ATF-2 element, located at -54 upstream of the cyclin D1 promoter transcription start site. Transcriptional activation of cyclin $\mathrm{Dl}$ by $\mathrm{E}_{2}$ and $16 \alpha-\mathrm{OHE}_{1}$ is dependent on phosphorylation and binding of ATF-2 to the CRE/ATF motif. Our results demonstrate an antiestrogenic effect of $2-\mathrm{ME}_{2}$ in MCF-7 breast cancer cells, and suggest that cyclin D1 might be a key target in the growth-inhibitory actions of $2-\mathrm{ME}_{2}$. Our results also indicate that transduction of the estrogenic signal for cell proliferation includes phosphorylation cascades involving the activation of p38 MAP kinase.

\section{Acknowledgements}

This work was supported by National Institutes of Health grants CA42439, CA42439S1, CA73058, CA73058S1, CA80163 (to T T \& T J T), ES05022 (to M A G), CA75503, CA70896, CA86072, CA93596 (to R G P) and AG20337 (to C A), and grants from the UMDNJ Foundation (to T T) and the Susan G Komen Breast Cancer Foundation (to R G P and T T). R G P is a recipient of the Weil Caulier Irma T Hirschl Career Scientist award.

\section{References}

Abdel-Hafiz HA, Heasley LE, Kyriakis JM, Avruch J, Kroll DJ, Johnson GL \& Hoeffler JP 1992 Activating transcription factor-2 DNA-binding activity is stimulated by phosphorylation catalyzed by $\mathrm{p} 42$ and p 54 microtubule-associated protein kinases. Molecular Endocrinology 6 2079-2089.

Albanese C, Johnson J, Watanabe G, Eklund N, Vu D, Arnold A \& Pestell RG 1995 Transforming p21 ras mutants and c-Ets-2 activate the cyclin D1 promoter through distinguishable regions. Fournal of Biological Chemistry 270 23589-23597.

Altucci L, Addeo R, Cicatiello L, Dauvois S, Parker MG, Truss M, Beato M, Sica V, Bresciani F \& Weisz A 1996 17 $\beta$-Estradiol induces cyclin D1 gene transcription, p36D1-p34 cdk4 complex activation and $\mathrm{p} 105 \mathrm{Rb}$ phosphorylation during mitogenic stimulation of $\mathrm{G}(1)$-arrested human breast cancer cells. Oncogene 12 2315-2324.

Altucci L, Addeo R, Gicatiello L, Germano D, Pacilio C, Battista T, Cancemi M, Petrizzi VB, Bresciani F \& Weisz A 1997 Estrogen induces early and timed activation of cyclin-dependent kinases 4 , 5 , and 6 and increases cyclin messenger ribonucleic acid expression in rat uterus. Endocrinology 138 978-984.

Aronica SM, Kraus WL \& Katzenellenbogen BS 1994 Estrogen action via the cAMP signaling pathway: stimulation of adenylate cyclase and cAMP-regulated gene transcription. PNAS 91 8517-8521.

Ball P, Knuppen R, Haupt M \& Breuer H 1972 Interactions between estrogens and catechol amines. III. Studies on the methylationof catechol estrogens, catechol amines and other catechols by the catechol $O$-methyltransferase of human liver. Foumal of Clinical Enodcrinology and Metabolism $\mathbf{3 4}$ 736-746.

Beier F, Lee RJ, Taylor AC, Pestell RG \& LuValle P 1999 Identification of the cyclin Dl gene as a target of activating transcription factor 2 in chondrocytes. PNAS 96 1433-1438.

Berthois Y, Katzenellenbogen JA \& Katzenellenbogen BS 1986 Phenol red in tissue culture media is a weak estrogen: implications concerning the study of estrogen responsive cells in culture. PNAS 83 2496-2500.

Bromberg JF, Wrzeszczynska MH, Devgan G, Zhao Y, Pestell RG, Albanese C \& Darnell JE Jr 1999 Stat3 as an oncogene. Cell 98 295-303.

Brown JR, Nigh E, Lee RJ, Ye, H, Thompson MA, Saudou F, Pestell RG \& Greenberg ME 1998 Fos family members induce cell cycle entry by activitating cyclin D1. Molecular and Cellular Biology 18 5609-5619.

Brueggemeier RW, Bhat AS, Lovely CJ, Coughenour HD, Joomprabutra S, Weitzel DH, Vandre DD, Yusuf F \& Burak WE Jr 2001 2-Methoxymethylestradiol: a new 2-methoxy estrogen analog that exhibits antiproliferative activity and alters tubulin dynamics. Fournal of Steroid Biochemistry and Molecular Biology 78 $145-156$.

Carlisle DL, Devereux WL, Hacker A, Woster PM \& Casero RA Jr 2002 Growth status significantly affects the response of human lung cancer cells to antitumor polyamine-analogue exposure. Clinical Cancer Research 8 2684-2689.

Castoria G, Migliaccio A, Bilancio A, Di Domenico M, de Falco A, Lombardi M, Fiorentino R, Varricchio L, Barone MV \& Auricchio F 2001 PI3-kinase in concert with Src promotes the S-phase entry of oestradiol-stimulated MCF-7 cells. EMBO Fournal 20 6050-6059.

Chinenov Y \& Kerppola T 2001 Close encounters of many kinds: Fos-Jun interactions that mediate transcription regulatory specificity. Oncogene 20 2438-2452

Cushman M, He HM, Katzenellenbogen JA, Lin CM \& Hamel E 1995 Synthesis, antitubulin and antimitotic activity, and cytotoxicity of analogs of 2-methoxyestradiol, an endogenous mammalian metabolite of estradiol that inhibits tubulin 
polymerization by binding to the colchicine binding site. Fournal of Medical Chemistry 38 2041-2049.

D'Amato RJ, Lin CM, Flynn E, Folkman J \& Hamel E 1994 2-Methoxyestradiol, an endogenous mammalian metabolite, inhibits tubulin polymerization by interacting at the colchicine site. PNAS 91 3964-3968.

D'Amico M, Hulit J, Amanatullah DF, Zafonte BT, Albanese C, Bouzahzah B, Fu M, Augenlicht LH, Donehower LA, Takemaru K, Moon RT, Davis R, Lisanti MP, Shtutman M, Zhurinsky J, Ben-Ze'ev A, Troussard AA, Dedhar S \& Pestell RG 2000 The integrin-linked kinase regulates the cyclin Dl gene through glycogen synthase kinase 3 beta and cAMP-responsive element-binding protein-dependent pathways. Fournal of Biological Chemistry 275 32649-32657.

Doisneau-Sixou SF, Sergio CM, Carroll JS, Hui R, Musgrove EA \& Sutherland RL 2003 Estrogen and antiestrogen regulation of cell cycle progression in breast cancer cells. Endocrine-Related Cancer $\mathbf{1 0}$ 179-186.

Dubey RK, Gillespie DG, Zacharia LC, Rosselli M, Korzekwa KR, Fingerle J \& Jackson EK 2000 Methoxyestradiols mediate the antimitogenic effects of estradiol on vascular smooth muscle cells via estrogen receptor-independent mechanisms. Biochemical and Biophysical Research Communications 278 27-33.

Falkenstein E, Tillmann HC, Christ M, Feuring M \& Wehling M 2000 Multiple actions of steroid hormones - a focus on rapid, nongenomic effects. Pharmacological Reviews 52 513-556.

Filardo EJ, Quinn JA, Frackelton AR Jr \& Bland KI 2002 Estrogen action via the $G$ protein-coupled receptor, GPR30: stimulation of adenylyl cyclase and cAMP-mediated attenuation of the epidermal growth factor receptor-to-MAPK signaling axis. Molecular Endocrinology 167084.

Fishman J \& Martucci CP 1980 Biological properties of 16 alphahydroxyesterone: implications of estrogen physiology and pathophysiology. Fournal of Clinical Endocrinology and Metabolism 51 611-615.

Foster JS \& Wimalasena J 1996 Estrogen regulates activity of cyclindependent kinases and retinoblastoma protein phosphorylation in breast cancer cells. Molecular Endocrinology $10488-498$.

Foster JS, Henley DC, Ahamed S \& Wimalasena J 2001 Estrogens and cell-cycle regulation in breast cancer. Trends in Endocrinology and Metabolism 12 320-327.

Fotsis T, Zhang Y, Pepper MS, Adlercreutz H, Montesanno R, Nawroth PP \& Schwelgerer L 1994 The endogenous oestrogen metabolite 2-methoxyestradiol inhibits angiogenesis and suppresses tumor growth. Nature 368 237-239.

Fuqua A, Fitzgerald SD, Chamness GC, Tandon AK, McDonnell DP, Nawaz Z, O'Malley BW \& McGuire WL 1991 Variant human breast tumor estrogen receptor with constitutive transcriptional activity. Cancer Research 51 105-109.

Golebiewska J, Rozwadowski P, Spodnik JH, Knap N, Wakabayashi T \& Wozniak M 2002 Dual effect of 2-methoxyestradiol on cell cycle events in human osteosarcoma 143B cells. Acta Biochimica Polonica 49 59-65.

Gupta S, Campbell D, Derijard B \& Davis RJ 1995 Transcription factor ATF2 regulation by the JNK signal transduction pathway. Science 267 389-393.

Gupta M, McDougal A \& Safe S 1998 Estrogenic and antiestrogenic activities of $16 \alpha$ - and 2-hydroxy metabolites of $17 \beta$-estradiol in MCF-7 and T47D human breast cancer cells. Fournal of Steroid Biochemistry and Molecular Biology 67 413-419.

Guttridge DC, Albanese C, Reuther JY, Pestell RG \& Baldwin AS 1999 NF-кB controls cell growth and differentiation through transcriptional regulation of cyclin D1. Molecular Cell Biology 19 5785-5799.

Hai TW, Liu F, Coukos WJ \& Green MR 1993 Transcription factor ATF cDNA clones: an extensive family of leucine zipper proteins able to selectively form DNA-binding heterodimers. Genes and Development 3 2083-2090.
Henderson BE, Ross R \& Berstein L 1988 Estrogens as a cause of human cancer: the Richard and Hinda Rosenthal Foundation award lecture. Cancer Research 48 246-253.

Herber B, Truss M, Beato M \& Muller R 1994 Inducible regulatory elements in the human cyclin D1 promoter. Oncogene $\mathbf{9}$ 1295-1304.

Jefcoate CR, Liehr JG, Santen RJ, Sutter TR, Yager JD, Yue W, Santner SJ, Tekmal R, Demers L, Pauley R, Naftolin F, Mor G \& Berstein L 2000 Tissue-specific synthesis and oxidative metabolism of estrogens. Fournal of the National Cancer Institute Monographs 27 95-112.

Katazenellenbogen BS, Montano MM, Ediger TR, Sun J, Ekena K, Laz Martini PG, McInerney EM, Delage-Mourrous R, Weis K \& Katzenellenbogen JA 2000 Estrogen receptors: selective ligands, partners, and distinctive pharmacology. Recent Progress in Hormone Research 55 163-193.

Kawasaki H, Taira K \& Yokoyama K 2000 Histone acetyltransferase (HAT) activity of ATF-2 is necessary for the CRE-dependent transcription. Nucleic Acids Symposium Series 44 259-260.

Kinoshita Y \& Chen S 2003 Induction of aromatase (CYP19) expression in breast cancer cells through a nongenomic action of estrogen receptor alpha. Cancer Research 63 3546-3555.

Klauber N, Parangi S, Flynn E, Hamel E \& D'Amato RJ 1997 Inhibition of angiogenesis and breast cancer in mice by the microtubule inhibitors 2-methoxyestradiol and taxol. Cancer Research 57 81-86.

Kousteni S, Bellido T, Plotkin LI, O'Brien CA, Bodenner DL, Han L, Han K, DiGregorio B, Katzenellenbogen JA,

Katzenellenbogen BS, Roberson PK, Weinstein RS, Jilka R \& Manolagas SC 2001 Nongenotropic, sex-nonspecific signaling through the estrogen or androgen receptors: dissociation from transcriptional activity. Cell $\mathbf{1 0 4} 719-730$.

Kumar AP, Garcia GE \& Slaga TJ 2001 2-Methoxyestradiol blocks cell-cycle progression at G2/M phase and inhibits growth of human prostate cancer cells. Molecular Carcinogenesis $\mathbf{3 1}$ $111-124$.

Laudet V, Hanni C, Coll J, Catzeflis F \& Stehelin D 1992 Evolution of the nuclear receptor gene superfamily. EMBO Fournal 11 $1003-1012$.

Lee RJ, Albanese G, Stenger RJ, Watanabe G, Inghirami G, Haines GK, Webster M, Muller WJ, Brugge JS, Davis RJ \& Pestell RG 1999 pp60 v-src induction of cyclin D1 requires collaborative interactions between the extracellular signal-regulated kinase, p38, and Jun kinase pathways. Foumal of Biological Chemistry 274 $7341-7350$.

Lewis JS, Thomas TJ, Klinge CM, Gallo MA \& Thomas T 2001 Regulation of cell cycle and cyclins by $16 \alpha$-hydroxyestrone in MCF-7 breast cancer cells. Fournal of Molecular Endocrinology 27 293-307.

Liu MM, Albanese C, Anderson CM, Hilty K, Webb P, Uht RM, Price RH Jr, Pestell RG \& Kushner PJ 2002 Opposing action of estrogen receptors alpha and beta on cyclin Dl gene expression. Fournal of Biological Chemistry 277 24353-24360.

Livingstone C, Patel G \& Jones N 1995 ATF-2 contains a phosphorylation-dependent transcriptional activation domain. EMBO Fournal 14 1785-1797.

Lottering ML, Haag M \& Seegers JC 1992 Effects of $17 \beta$-estradiol metabolites on cell cycle events in MCF-7 cells. Cancer Research $\mathbf{5 2}$ 5926-5932.

Madrid LV, Mayo MW, Reuther JY \& Baldwin AS Jr 2001 Akt stimulates the transactivation potential of the RelA/p65 subunit of NF-kappa B through utilization of the Ikappa B kinase and activation of the mitogen-activated protein kinase p38. Fournal of Biological Chemistry 276 18934-18940.

Margeat E, Bourdoncle A, Margueron R, Poujol N, Cavailles V \& Royer C 2003 Ligands differentially modulate the protein 
interactions of the human estrogen receptors alpha and beta. fournal of Molecular Biology 326 77-92.

Markaverich BM \& Clark JH 1979 Two binding sites for estradiol in rat uterine nuclei: relationship to uterotropic response. Endocrinology 105 1458-1462.

Marquez DC \& Pietras RJ 2001 Membrane-associated binding sites for estrogen contribute to growth regulation of human breast cancer cells. Oncogene 20 5420-5430.

Martucci CP \& Fishman 1993 J P450 enzymes of estrogen metabolism. Pharmacological Therapy 57 237-257.

McKenna NJ \& O'Malley BW 2002 Minireview: nuclear receptor coactivators - an update. Endocrinology 143 2461-2465.

Migliaccio A, Di Domenico M, Gastoria G, de Falco A, Bontempo P, Nola E \& Auricchio F 1996 Tyrosine kinase/p21 reas/MAP-kinase pathway activation by estradiol-receptor complex in MCF-7 cells. EMBO Journal 15 1292-1300.

Mooberry SL 2003 Mechanism of action of 2-methoxyestradiol: new developments. Drug Resistance Updates 6 355-361.

Musgrove EA, Lee CS, Buckley MF \& Sutherland RL 1994 Cyclin D1 induction in breast cancer cells shortens $G_{1}$ and is sufficient for cells arrested in $\mathrm{G}_{1}$ to complete the cell cycle. PNAS 91 8022-8026.

Muti P, Bradlow HL, Micheli A, Krogh V, Freudenheim JL, Schunemann HJ, Stanulla M, Yang J, Sepkovic DW, Trevisan M \& Berrino F 2000 Estrogen metabolism and risk of breast cancer: a prospective study of the 2:16 alpha-hydroxyestrone ratio in premenopausal and postmenopausal women. Epidemiology 11 635-640.

Nilsson S \& Gustafsson JA 2002 Estrogen receptor action. Critical Reviewes in Eukaryotic Gene Expression 12 237-257.

Pacilio C, Germano D, Addeo R, Altucci L, Petrizzi VB, Cancemi M, Cicatiello L, Salzano S, Lallemand F, Michalides RJ, Bresciani F \& Weisz A 1998 Constitutive overexpression of cyclin D1 does not prevent inhibition of hormone-responsive human breast cancer cell growth by antiestrogens. Cancer Research $\mathbf{5 8}$ 871-876.

Pestell RG, Albanese C, Reutens AT, Segall JE, Lee RJ \& Arnold A 1999 The cyclins and cyclin-dependent kinase inhibitors in hormonal regulation of proliferation and differentiation. Endocrine Reviewes 20 501-534.

Planas-Silva MD, Donaher JL \& Weinberg RA 1999 Functional activity of ectopically expressed estrogen receptor is not sufficient for estrogen-mediated cyclin D1 expression. Cancer Research $\mathbf{5 9}$ $4788-4792$.

Prall OW, Sarcevic B, Musgrove EA, Watts GK \& Sutherland RL 1997 Estrogen-induced activation of Cdk4 and Cdk2 during $\mathrm{G}_{1}-\mathrm{S}$ phase progression is accompanied by increased cyclin D1 expression and decreased cyclin-dependent kinase inhibitor association with cyclin E-Cdk2. Journal of Biological Chemistry 272 10882-10894.

Pribluda VS, Gubish ER Jr, Lavallee TM, Treston A, Swartz GM \& Green SJ 2000 2-Methoxyestradiol: an endogenous antiangiogenic and antiproliferative drug candidate. Cancer and Metastasis Reviewes 19 173-179.

Raingeaud J, Whitmarsh AJ, Barrett T, Derijard B \& Davis RJ 1996 MKK3- and MKK6-regulated gene expression is mediated by the p38 mitogen-activated protein kinase signal transduction pathway. Molecular and Cellular Biology 16 1247-1255.

Razandi M, Pedram A, Greene GL \& Levin ER 1999 Cell membrane and nuclear estrogen receptors derive from a single transcript: studies of ER $\alpha$ and ER $\beta$ expressed in CHO cells. Molecular Endocrinology 13 307-319.

Recio JA \& Merlino G 2002 Hepatocyte growth factor/scatter factor activates proliferation in melanoma cells through p38 MAPK, ATF-2 and cyclin D1. Oncogene 2 1000-1008.

Robertson JF 2001 Faslodex (ICI 182, 780), a novel estrogen receptor downregulator - future possibilities in breast cancer. fournal of Steroid Biochemistry and Molecular Biology 79 209-212.
Russo J, Hasan Lareef M, Balogh G, Guo S \& Russo IH 2003 Estrogen and its metabolites are carcinogenic agents in human breast epithelial cells. Fournal of Steroid Biochemistry and Molecular Biology 87 1-25.

Sabbah M, Courilleau D, Mester J \& Redeuilh G 1999 Estrogen induction of the cyclin D1 promoter: involvement of a cAMP response-like element. PNAS 96 11217-11222.

Schumacher G \& Neuhaus P 2001 The physiological estrogen metabolite 2-methoxyestradiol reduces tumor growth and induces apoptosis in human solid tumors. Fournal of Cancer Research and Clinical Oncology 127 405-410.

Seegers JC, Aveling M-L, van Aswegen CH, Cross M, Koch F \& Joubert WS 1989 The cytotoxic effects of estradiol-17 $\beta$, catecholestradiols, and methoxyestradiols on dividing MCF-7 and HeLa cells. Fournal of Steroid Biochemistry 32 797-809.

Shah N, Thomas TJ, Lewis JS, Klinge CM, Shirahata A, Gelinas C \& Thomas T 2001 Regulation of estrogenic and nuclear factor kappa B functions by polyamines and their role in polyamine analog-induced apoptosis of breast cancer cells. Oncogene $\mathbf{2 0}$ $1715-1729$.

Shoulars K, Brown T, Alejandro MA, Crowley J \& Markaverich BM 2002 Identification of nuclear type II [(3)H]estradiol binding sites as histone H4. Biochemical and Biophysical Research Communications $2961083-1090$.

Sicinski P \& Weinberg RA 1997 A specific role for cyclin D1 in mammary gland development. Fournal of Mammary Gland Biology and Neoplasia 2 335-342.

Song RX, McPherson RA, Adam L, Bao Y, Shupnik M, Kumar R \& Santen RJ 2002 Linkage of rapid estrogen action to MAPK activation by ERalpha-Shc association and Shc pathway activation. Molecular Endocrinology 16 116-127.

Song RX, Barnes CJ, Zhang Z, Bao Y, Kumar R \& Santen RJ 2004 The role of Shc and insulin-like growth factor 1 receptor in mediating the translocation of estrogen receptor alpha to the plasma membrane. PNAS $1012076-2081$.

Stoica GE, Franke TF, Wellstein A, Czubayko F, List HJ, Reiter R, Morgan E, Martin MB \& Stoica A 2003 Estradiol rapidly activates Akt via the ErbB2 signaling pathway. Molecular Endocrinology 17 818-830.

Suto A, Telang NT, Tanino H, Takeshita T, Ohmiya H, Osborne MP \& Kubota T 1999 In vitro and in vivo modulation of growth regulation in the human breast cancer cell line MCF-7 by estradiol metabolites. Breast Cancer 6 87-92.

Sutherland RL \& Musgrove EA 2004 Cyclins and breast cancer. Journal of Mammary Gland Biology and Neoplasia 9 95-104.

Teyssier C, Belguise K, Galtier F \& Chalbos D 2001 Characterization of the physical interaction between estrogen receptor alpha and JUN proteins. Fournal of Biological Chemistry 276 36361-36369.

Thomas T \& Thomas TJ 1994 Regulation of cyclin B1 by estradiol and polyamines in MCF-7 breast cancer cells. Cancer Research $\mathbf{5 4}$ $1077-1084$

Thomas T, Trend B, Butterfield JR, Janne OA \& Kiang DT 1989 Regulation of ornithine decarboxylase gene expression in MCF-7 breast cancer cells by antiestrogens. Cancer Research 49 5852-5857.

Thomas T, Gallo MA \& Thomas TJ 2004 Estrogen receptors as targets of drug development for breast cancer, osteoporosis and cardiovascular diseases. Current Cancer Drug Targets 4 483-499.

Uht RM, Anderson CM, Webb P \& Kushner PJ 1997 Transcriptional activities of estrogen and glucocorticoid receptors are functionally integrated at the AP-1 response element. Endocrinology 138 2900-2908.

van Dam H, Wilhelm D, Herr I, Steffen A, Herrlich P \& Angel P 1995 ATF-2 is preferentially activated by stress-activated protein kinases to mediate c-jun induction in response to genotoxic agents. EMBO Fournal 14 1798-1811.

Waas WF, Lo HH \& Dalby KN 2001 The kinetic mechanism of the dual phosphorylation of the ATF2 transcription factor by p38 
mitogen-activated protein (MAP) kinase alpha. Implications for signal/response profiles of MAP kinase pathways. Fournal of Biological Chemistry 276 5676-5684.

Wade CB, Robinson S, Shapiro RA \& Dorsa DM 2001 Estrogen receptor (ER)alpha and ERbeta exhibit unique pharmacologic properties when coupled to activation of the mitogen-activated protein kinase pathway. Endocrinology 142 2336-2342.

Wang TC, Cardiff RD, Zukerberg L, Lees E, Arnold A \& Schmidt EV 1994 Mammary hyperplasia and carcinoma in MMTV-cyclin D1 transgenic mice. Nature 369 669-671.

Watanabe G, Howe A, Lee RJ, Albanese C, Shu IW, Karnezis AN, Zon L, Kyriakis J, Rundell K \& Pestell RG 1996 Induction of cyclin D1 by simian virus 40 small tumor antigen. PNAS 93 12861-12866.

Watanabe G, Albanese C, Lee RJ, Reutens A, Vairo G, Henglein B \& Pestell RG 1998 Inhibition of cyclin D1 kinase activity is associated with E2F-mediated inhibition of cyclin D1 promoter activity through E2F and Sp1. Molecular and Cellular Biology 18 3212-3222.

Weatherman RV, Chang CY, Clegg NJ, Carroll DC, Day RN, Baxter JD, McDonnell DP, Scanlan TS \& Schaufele F 2002
Ligand-selective interactions of ER detected in living cells by fluorescence resonance energy transfer. Molecular Endocrinology 16 487-496.

Yamakawa K \& Arita J 2004 Cross-talk between the estrogen receptor-, protein kinase A-, and mitogen-activated protein kinase-mediated signaling pathways in the regulation of lactotroph proliferation in primary culture. Fournal of Steroid Biochemistry and Molecular Biology 88 123-130.

Zhu BT \& Conney AH 1998 Is 2-methoxyestradiol an endogenous estrogen metabolite that inhibits mammary carcinogenesis? Cancer Research 58 2269-2277.

Zwijsen RM, Buckle RS, Hijmans EM, Loomans CJ \& Bernards R 1998 Ligand-independent recruitment of steroid receptor coactivators to estrogen receptor by cyclin D1. Genes and Development 12 3488-3498.

Received 15 July 2004

Accepted 13 September 2004

Made available online as an Accepted Preprint

29 September 2004 